\title{
GIANTS OF PHYSICAL CULTURE RAFAEL AND DUŠANKA BAN
}

\author{
Vladimir Kebin \\ University of Belgrade, Serbia
}

UDK 796.03:929 Ban Rafael i Dušanka

012 Ban Rafael i Dušanka

\section{SUMMARY}

Having had the opportunity to live with Bans for a period of time and having analysed their biographic and bibliographic data, as well as the entirety of their scientific work, the author comes to the conclusion that the members of Ban family, both father and daughter, had dedicated their entire lives to physical culture. The opus of Rafael and dr Dušanka Ban has been founded on a carefully nurtured sportsokol lifestyle. Based on their entire opus, the author believes that there are people of a certain kind, the rare and extraordinary ones, who relish the burden of creatorship in their field of expertise-physical culture. They set up new guidelines and in the process reexamine the foundational premises of physical culture, in theory as well as in practice.

Keywords:analysis of biographic and bibliographic data, creatorship, contribution, new guidelines/

\section{INTRODUCTION}

They devoted their entire lives to their greatest love called physical culture.

"We believe that there is always a certain type of people somewhere - rare and exceptional people who relish the efforts of creation in their vocation. 
We believe that this is not just a small number of people, but a whole team that can set a new mark.

Setting a new mark is possible if we re-examine the basic premises of physical education, sports, recreation, and decide what we want."

That is how Rafael and Dušanka Ban spoke, thought and acted all their lives.

I have to start the story about the Bans, giants of physical culture in our country, with an analysis of the origin of their style of behaviour, i.e., lifestyle. I am mentioning this because I had the opportunity to get acquainted with the creative endeavour of Rafael and Dušanka Ban, living with them, sharing the space, every detail of which showed their creative activity in physical culture, I would say, you could sense a permanent atmosphere of creativity.

Browsing through the Ban family's large personal library of some 3,000 neatly systematized books, of which over 2,500 various professional books, dictionaries, journals, encyclopaedias, documents in five foreign languages, I have always wondered what driving force in the human spirit makes a family dedicate the entire lives to physical culture.

The conclusion was always the same: The Bans lived a life imbued with the spirit of Sokol, of sports - they built a sports style of behaviour and living.

\section{Question and problem}

Some nuances that speak of real life slip through everyday life; a reflection different from everything that is usually seen: beauty, justice, friendship, the experience of the meaning of life filled with the fullness of joy and pleasure. This leads a person to wish for some impossible time in which these reflections would last, multiply and be transformed into a constant light, into a certain reality. No matter how sincere and profound it may be, this wish does not indicate an immediate practical action that would lead to its fulfilment. The wish like that is not exhausted but is fully realized within the framework of nostalgic daydreaming because it is its medium and even its tissue. In such circumstances, a person does not care so much about achieving the better as about the wish for the better. All these questions allow for a complete elaboration and attention. A sense of the future implies a mental capacity that is voluntarily educated. But in order to selfeducate, we must know in what direction life and society are developing.

\section{Second-order problem - put in the foreground}

Here we need to talk about a second-order problem that, depending on how we approach things, can be brought to the fore. The problem of a receptive act is a discussion about a productive act, but it can also be reversed, because often the 
meaning of production is clearly revealed only in the appropriate reception. It is therefore a matter of creative understanding. If creation means the possibility of shaping the world according to your own ideals, then there is no doubt that man has this possibility and uses it more or less every day. In that sense, man is a creative being. But, it is also beyond a doubt that man realizes their ideals in the most unobstructed, and therefore most complete, way. Ideals can be realized in sport, too. With the help of basic forms of sports existence, training and competition, a sports person is also a sports creator. Therefore, there is no doubt that in that sense one can speak of sports creation as one of the purest forms of creation. "Creation in sport belongs to human activity, which characterizes all creators of human acts. However, due to the specifics of sport, creation and acts in sport have certain specific characteristics. The specifics separate activity in sport, sports creation and sports acts from other forms of human activity and creation. Emphasizing the distances and differences between creation in sport and creation in other activities (work, art, politics, etc.) is not a mere formality; it is a challenge to human cognition and the process of humanizing of man." (Kostić Radmila and Kostić Radomir: Teorija filozofske osnove sporta (Theory of the Philosophical Basis of Sport), Niš, 1997, p.. 18)

What is the meaning in the creative and engaged? It should first be noted that the creative and engaged represent a particular life relationship in which selfinterest arises. Sartre calls it a "situation". In a creative and engaged understanding of something, man does not want to know what a thing is in itself, but what it is for them. In our context, this primarily refers to values - especially those presented as positive values.

- educativeness

- $\quad$ spirituality

- restlessness (motivation for change)

- transformation (self-realization)

- restlessness and passion

- $\quad$ experience - sports practice, sports career

- comprehension (abstraction)

- power

- $\quad$ sociality (self-interpretation)

- formativeness

- hygienic value

- biological effects

- $\quad$ positive educativeness 
- fascination of the unexpected

- the speed with which school sports spread

- globalization across national and territorial borders

- communicativeness

\section{Lifestyle}

All this is reflected in the projection of everyday life and lifestyle. "If we define the way of life of an individual or a group as a broader concept that encompasses the entire social existence of a person, then there is no doubt that a pattern of behaviour, manifesting a specific life orientation in meeting personal needs, is one of its best dimensions. These activities, or behavioural orientations, usually tell us something specific and characteristic about an individual or group of people within a particular culture or population. In socio-psychological literature, such specific models of existence, expression, communication and self-realization of individuals or groups are referred to as "lifestyle" or "lifestyles" (Fulgozi A., Radin F., Stilovi života zagrebačkih srednjoškolaca (The Lifestyles of Zagreb SecondarySchool Students), Naklada edd, Zagreb, 1982, p. 9).

The lifestyle is formed in early childhood; it soon becomes established, but later the individual can take on new expressions of their lifestyle. The lifestyle develops gradually over the course of a lifetime and day by day it manages and unites all or at least many of life's tasks. Each individual strives for a unique, relatively appropriate lifestyle. He/she - an individual builds a characteristic way of walking, thinking, reacting and maturing in order to be different from others.

If meeting the needs can be a strong determinant of behaviour, and the meeting the needs in young people can be achieved in sports activities, then we can talk about the possibility of building a personal and group style of behaviour that would be marked as a specific sports behaviour or sports style.

It is indisputable that the Bans, both father and daughter adopted and nurtured a sports style of behaviour in their lives and were devoted missionaries in transmitting all the positive theoretical and practical values of physical culture. 


\section{RAFAEL BAN \\ (1906 - 1987)}

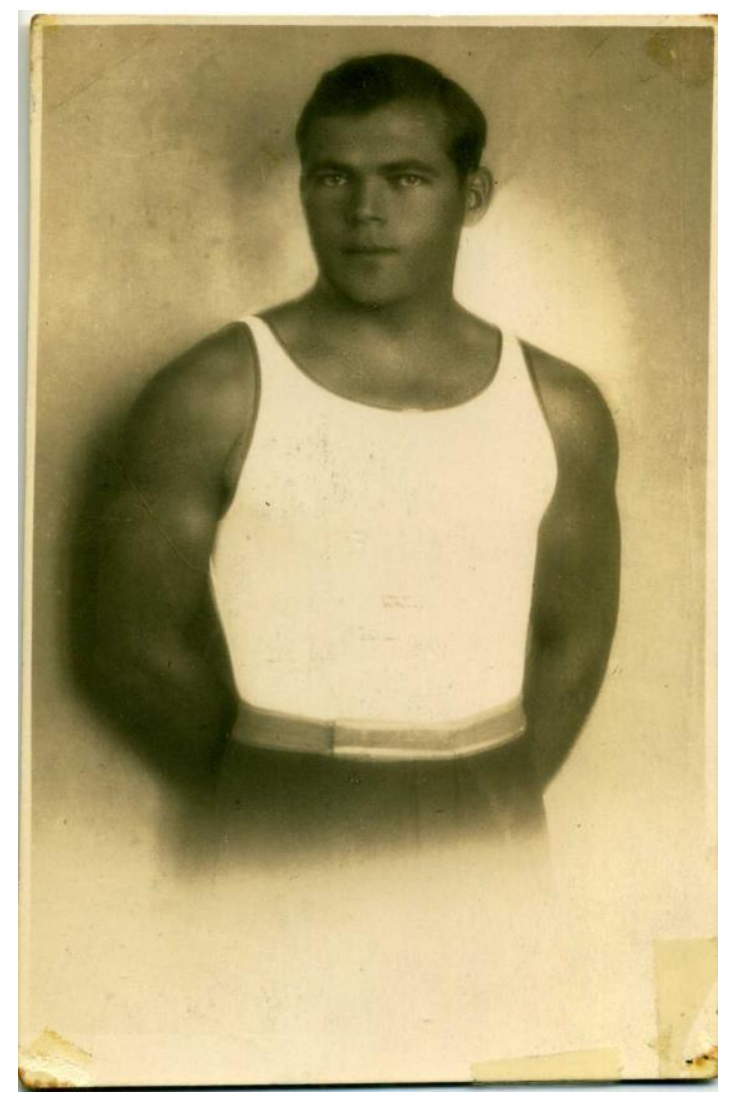

\section{SHORT BIOGRAPHY}

\section{Performer and competitor}

\section{Frontman and teacher}

Rafael Ban was born on November 27, 1906 in Sušak - Rijeka. His father (also) Rafael came from an impoverished peasant family from Ledinci near Novi Vinodolski. He worked hard all his life, spent some time in America, worked with his horses, he owned an inn and was a cattle trader and, in the end, he was a member of the craftsmen cooperative in Sušak, yet the financial situation of the 
family was never good. His mother Marija Kružić from Primorski Hreljin also came from a poor peasant family, the majority of whose members emigrated to America. She was a housewife.

Rafael Ban had a brother and a sister. After graduating, from secondary school, he worked for a while as a day labourer at the District Administration, then with his brother in a butcher's shop, and spent 2 months in Prague, as a worker in a meat processing shop, and then went back to Sušak, where he worked in the Zagreb Brewery's warehouse. In 1927/28, he graduated from the Military School for Reserve Infantry Officers in Sarajevo.

He started exercising at the age of seven, i.e., in 1913, at the Sokol Society in Sušak - Rijeka. The classes were held by Marijan Bros, the head of the Society, an independent craftsman - a bookbinder by profession. Until 1941, R. Ban performed the voluntary duties of the head of the Society and the Sušak - Rijeka District Sokol.

"We seriously studied drill exercises, received instructions on how to behave as members of the Sokol Society, how to greet each other; we also carefully prepared for public appearances because it was at excursions and public events where the Sokol programme was promoted, which was in tune to political programme at that time: awakening of national consciousness and resistance against Hungarianization, Italianization, Germanization. Most often we did it by means of physical exercise: "strength in our right hand, courage in everything, homeland in our thoughts." A large artistically crafted poster with this and similar slogans hung in the gym, and it can be said that it had a very impressive effect on the people who exercised." (from the autobiographical notes of R. Ban)

1914

performed at a public class on an occasional excursion in Škrljevo - Krasice in three exercises on parallel bars, Russian Dance and elements of the Cossack Circle

1914 participated in a public class in Hreljine: demonstrations of exercises with sticks and on parallel bars

26/07/1914 mobilization. The last session of the Sokol Society (of which R. Ban was a member and where he practiced) was held on July 22, 1914. The next session was held on October 28, 1918.

1917 - 1921 R. Ban completed 4 grades of the Lower Grammar School. At school, he often took part in demonstrations against the war, Austro-Hungarian Monarchy and Italian occupation of Rijeka, organized by senior pupils. 
From the first grade, he started playing football with his peers. Rijeka had 75 clubs.

Sušak is a place, says R. Ban in his notes, where the Croatian sports movement grew up against the Hungarian and Italian sports political paranoia. These were the beginnings of mountaineering, athletics, cycling, tennis, "while in football, rowing and swimming with water polo and dives, sciavi and croatazzi were soon giving their patronizing neighbours real school lessons".

1922

The General Assembly of the Sokol Society Sušak - Rijeka was held in January, and then the works in Sokolana began. The realized programme was very extensive: events, public performances, District Rally on Krk, public performance in Ogulin, performance on the occasion of the Patron Saint's Day of the 4th Infantry Regiment in Martinšćica, performance in Otočac, performance and competition at the Sokol Rally in Ljubljana, Social Frontmen Course - 13 participants. R. Ban was involved in all activities and performances in all events and competitions

Besides the regular sessions, he came to exercise on Saturdays and Sundays, provided that the gyms were cleaned and washed.

The main task that year was to prepare for participation in the First World Rally in Ljubljana. The key thing was to practice the exercises for the competition. After long meetings, the exercise of Dr. V. Murnik, then the president of the Yugoslav Sokol Federation, was accepted.

The dress rehearsal for the World Rally in Ljubljana was the rally of the Rijeka District on the Island of Krk.

For R. Ban, participation in the World Rally in Ljubljana in 1922 was very important for his later career. The competition programme was quite diverse. At this Rally, R. Ban performed in the lower starting grade (apparatus and athletics) and out of 160 competitors, he took the $40^{\text {th }}$ place.

When he returned to his Sokol gym, he met famous apparatus gymnast Janko Prelevac, who came from Ljubljana and held classes and a permanent frontmen course. Under his leadership, the trainees progressed rapidly.

1923 From the spring of that year, R. Ban was competing and practicing every day, along with attending school and working at his workplace.

1923

He won the first place at the District Rally competition in Gospić

1923 He won the first place at the District Rally in Sušak

1923

At the Regional Rally in Zagreb, he won the $9^{\text {th }}$ place in higher grade-levels 
1924

1924

1925

1925

1926

1926

At the $5^{\text {th }}$ district rally that marked the $20^{\text {th }}$ anniversary of the Sokol Society Sušak, he won the first place.

In August, in Zagreb, he won the $9^{\text {th }}$ place at the regional rally

The Society got another Slovenian gymnastics teacher, Milčo Kušćer from Trieste.

He won the $14^{\text {th }}$ place at the Federal Championship in Belgrade

The main event was participation in the Eighth World Sokol Rally in Prague

After the Rally, he remained in Prague. He worked as an apprentice in the Otokar Schmol workshop for meat processing and in the evenings in the Sokol Society Smetrov I and then in Karlin, where he practiced under the guidance of the world champion in gymnastic mixed all-around Frante Peskošek. He was well received in both societies and participated in all activities. That year he completed a course for training instructors in Prague and then returned to Sušak.

When he returned from Prague, he transfered his experience and the way of working to his Society.

1926

1927

1928

1928

1928

1930

1930
He was given the task to lead the category of male children from 12 to 14 years of age.

He works at the Society in Sušak and as an accountant for the Zagreb brewery.

From September 1927 to the end of May 1928, he finished the Military School for Reserve Infantry Officers in Sarajevo.

For a while after the course, he was unemployed in the army, and on Prelevac's recommendation, he applied for employment in Ljubljana in the Yugoslav Sokol Federation for the position of Federal Traveling Frontman.

On January 15, he took office at the Yugoslav Sokol Federation in Ljubljana and was at that job until 1941.

He participated in the World Gymnastics Championship and won the $4^{\text {th }}$ place on pommel horse.

At the World Championship in Luxembourg, he competed as a member of the team. This competition marked the end of his competition period and he devoted himself to educational work.

- He worked at the Sokol Association of the Kingdom of Yugoslavia from 1930 to April 1941.

- He was an officer in charge of sports at the National Labour Service for the Reconstruction of Serbia from 1942 to 1944. 
- In the Yugoslav People's Army (JNA), he was a teacher at a military educational institution from 1945 to 1962, and later the head of the JNA Military Sports Centre.

- In the Partizan Sports Federation of Yugoslavia (FISAJ) and the Partizan Gymnastics Association

1941 to February 1, 1945 After the bombing of Belgrade on April 6, 1941, he went to Loznica, by bicycle, and served as a reserve infantry lieutenant. In this period, he met many of his comrades who worked on the affirmation of the Sokol movement, physical education and sport throughout the Kingdom of Yugoslavia.

1944 After liberation, in 1944, he contacted the Military Academy of the Yugoslav Army (JA), where he became a physical education teacher, from 1945 to 1946.

1946

He worked at the Central House of Yugoslav Army (CDJA)

1947

1948

At the General Staff of the JA he was the commander of the Officers's Gymnastics School in Belgrade.

At the Olympic Games in London in 1948 and in Helsinki 1952, he was the coach of our gymnastics team.

\section{On April 7, 1987, Rafael Ban died in Belgrade.}

Two months before his death, he still exercised, held recreation classes, faithful to physical culture, sport and all the ideals from his youth. Rafael Ban, a former member of the gymnastics team, a participant in the World Championship in Luxembourg in 1930 and the winner of the fourth place in gymnastics on pommel horse, died. An athlete who once, together with Leon Štukelj, contributed to the participation of Yugoslav gymnastics in the World Championship, died.

Rafael Ban died at the age of 81, and in order to better understand an exceptional life biography, we will list the most important points. When Rafael Ban turned 16, he was a pre-war Sokol gymnast and an outstanding competitor in gymnastics and athletics. He went to Prague in 1923 to improve his skills and became an outstanding expert in gymnastics, football, boxing and athletics. In 1930, he became a member of the national team and then an instructor in Sokol and gymnastics.

In the first years after 1945, he worked as a gymnastics expert, and later became the head of the Military School for Physical Education in the JNA. He was the organizer and author of a series of rallies at the level of districts, municipalities and, later, the federal rallies held on May 25. He designed numerous exercises at the federal rallies for May 25, Youth Day. 
He went through all the stages of the development of physical culture in Yugoslavia; was a member of the executive body of the Sports Federation of Yugoslavia, Partizan of Yugoslavia and Serbia; the head of the independent Association in Belgrade, Partizan 6.

Rafael Ban was an ambassador of physical culture and sport. He was married to Jelka Vukmir Ban, who was a member of the Sokol Association from Sremska Mitrovica, and after 1945 until her retirement, she was the secretary of the Association for Physical Education Partisan of Yugoslavia and Serbia. His daughter, Prof. Dr. Dušanka Ban, a scientific advisor followed her father's footsteps; she graduated and received a master's and doctoral degree from the Faculty of Physical Education in Belgrade. She worked at the Yugoslav Institute for Physical Culture and Sports Medicine and was a professor in the country and abroad; engaged in sports documentation and sports information; published 274 scientific papers and was the leader of 60 projects. She spoke three foreign languages and was a member of the editorial board of the Fizička kultura Journal for 25 years; lifelong vice-president of IASI.

Rafael Ban published a large number of professional publications in the field of gymnastics and physical culture and sports. The most famous are Gymnastic Primer and Terminology of Apparatus Exercises. He held a huge number of professional conferences, classes and trainings. and participated in various rallies and competitions all over Europe as a trainer and coach. He retired in the rank of major.

There is a serious desire among experts in Serbia to compile a monograph on Rafael Ban, based on comprehensive research.

He intended to leave his huge written and illustrated documentation to the Museum of Physical Culture at the Faculty of Sports and Physical Education in Belgrade. The entire documentation on his life and work is in Belgrade, owned by Prof. Dr. Vladimir Kebin.

\section{A SELECTION FROM THE RICH LEGACY OF HIS PHOTO DOCUMENTATION}

Picture 1: "In 1920 Yugoslav sports club Hajduk in Trsat. The club was founded by the boys themselves (I was about 14) from the vicinity of Trsat. After 1900, numerous small clubs were spontaneously founded in the vicinity of Rijeka, following the example of the Croatian sports club Viktorija in Sušak. The photograph was taken in front of the Sušak Grammar School, where we played matches. It was the first time we wore the proper football boots (says R. Ban)" Down, in the front row from the left, sits Ban R. He played right-back. 


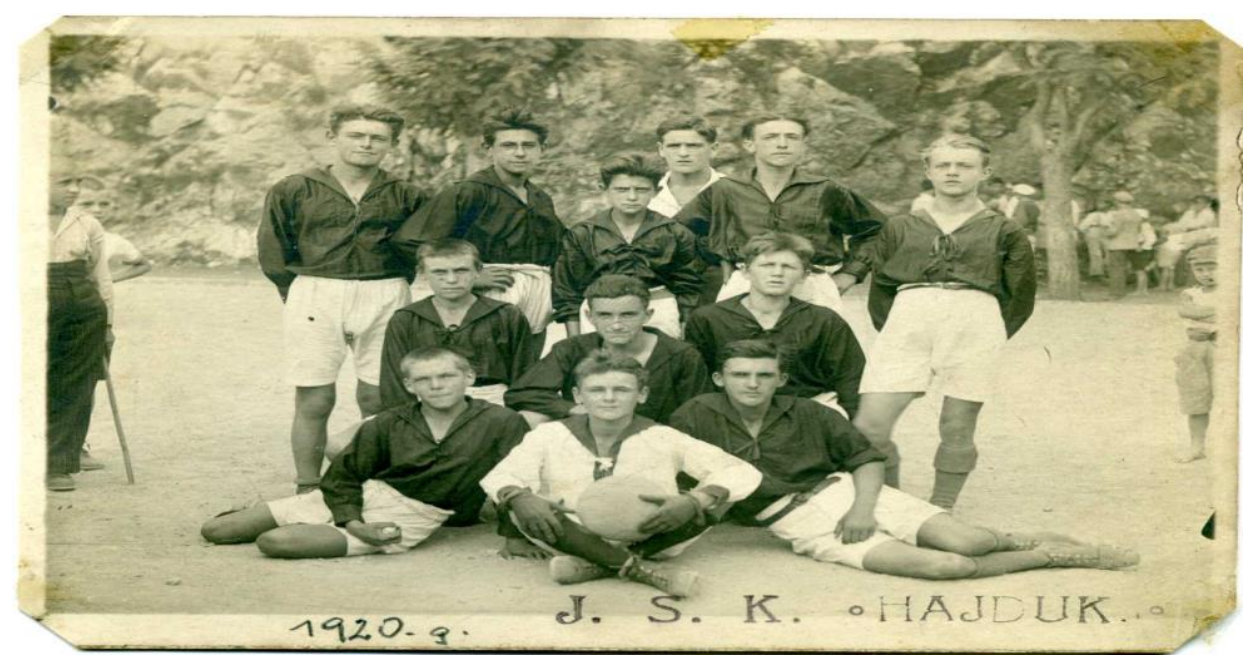

Picture 2: 1925 - Young foremen from Sušak for children's categories; R. Ban sitting in the first row, thefourth from the left.

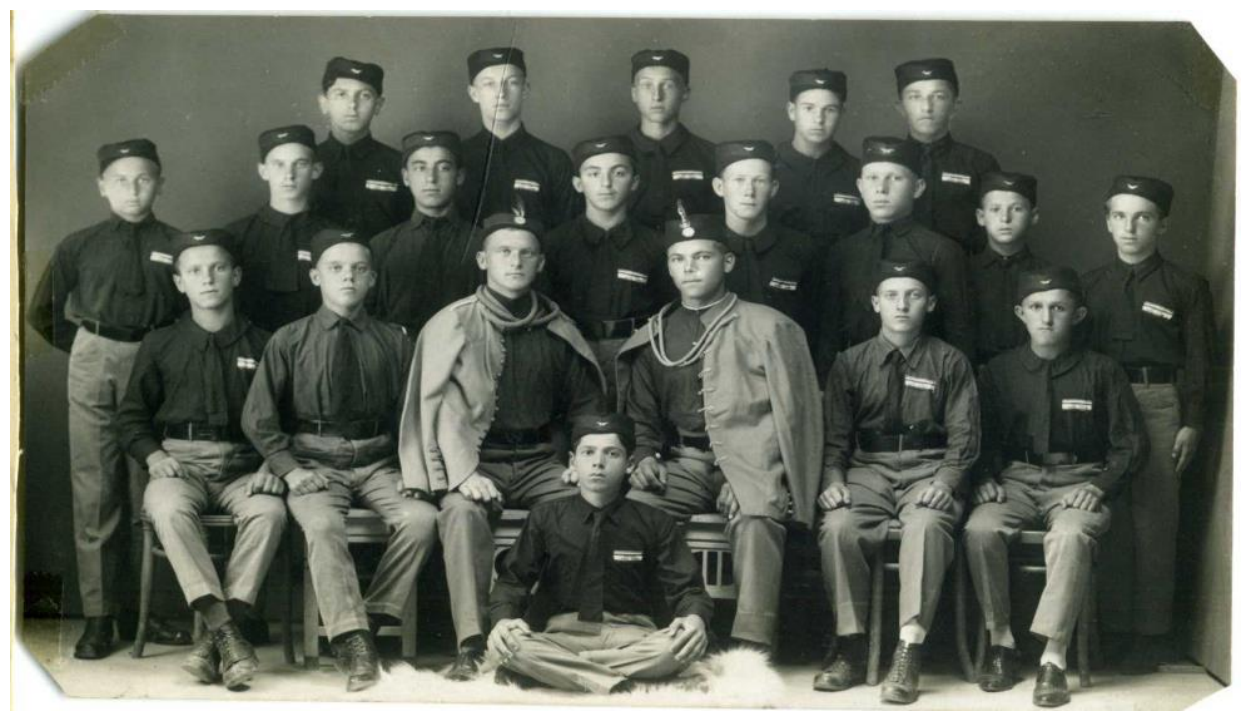


Picture 3: 1925 - Boxers of Viktorija. I trained for a few months in the boxing section of SD Viktorija, under the leadership of Evgeny Davydov (Russian emigrant, standing second on the left). R. Ban is the fourth from the left, standing.

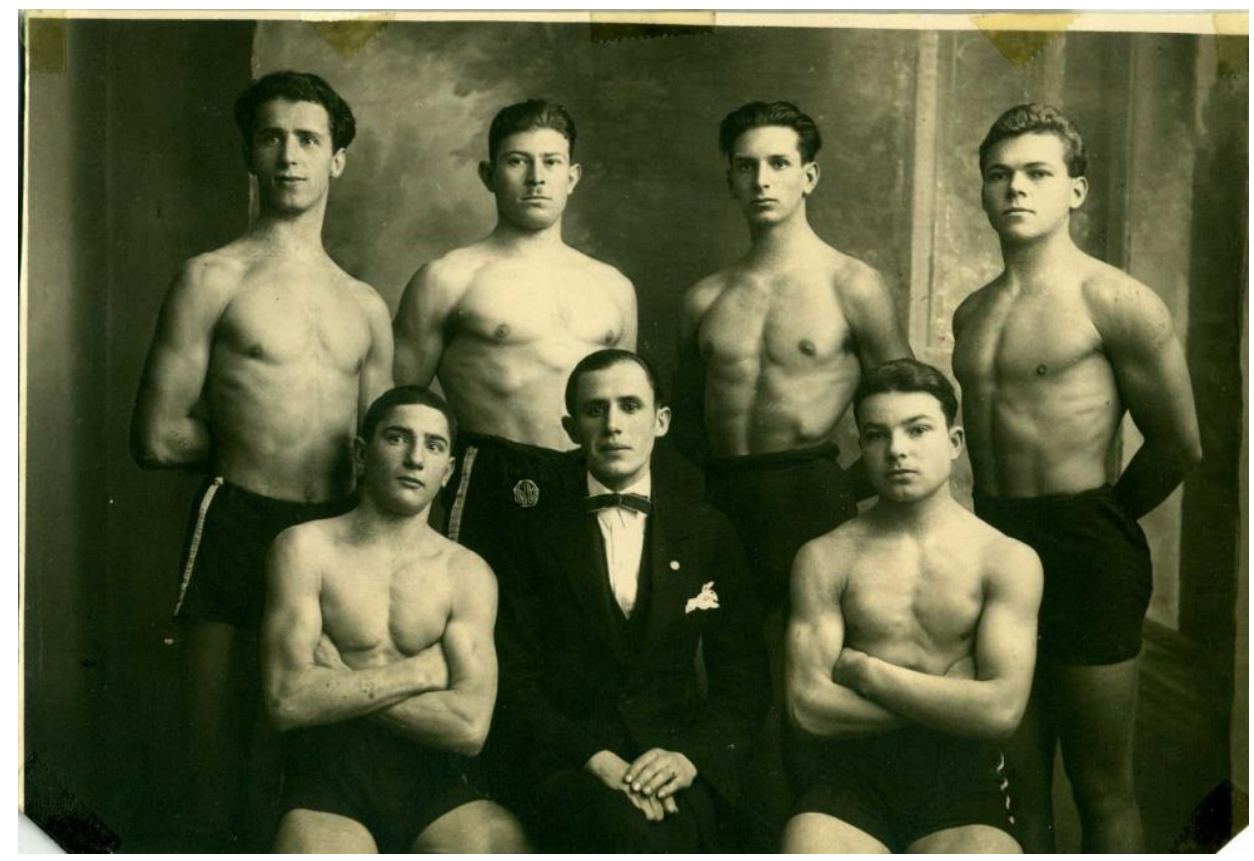

Picture 4: 1926 - New members of the frontmen staff of the Sušak Sokol (after completing the course). R. Ban is the first from the left.

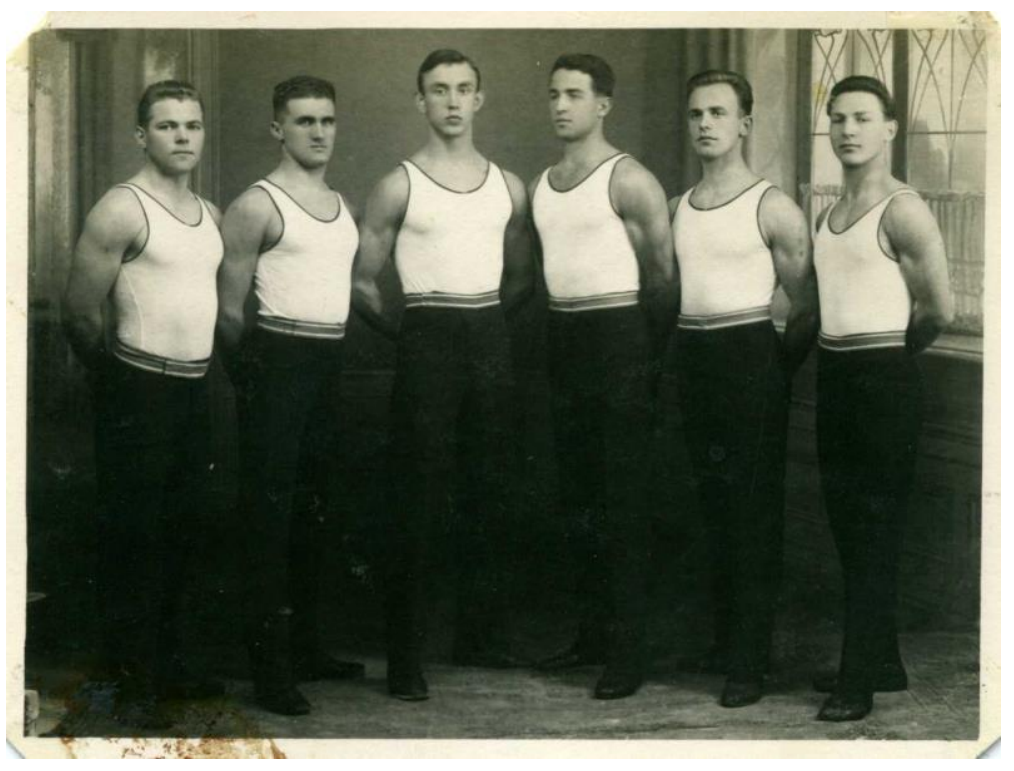


Picture 5: 1926 - Participants in a two-week course at the Coach School COS (Czechoslovak Obec Sokolska) in Prague in the gym of the Tyrš House (Tyršů dům). R. Ban is the first from the left in the middle row (third row from the bottom).

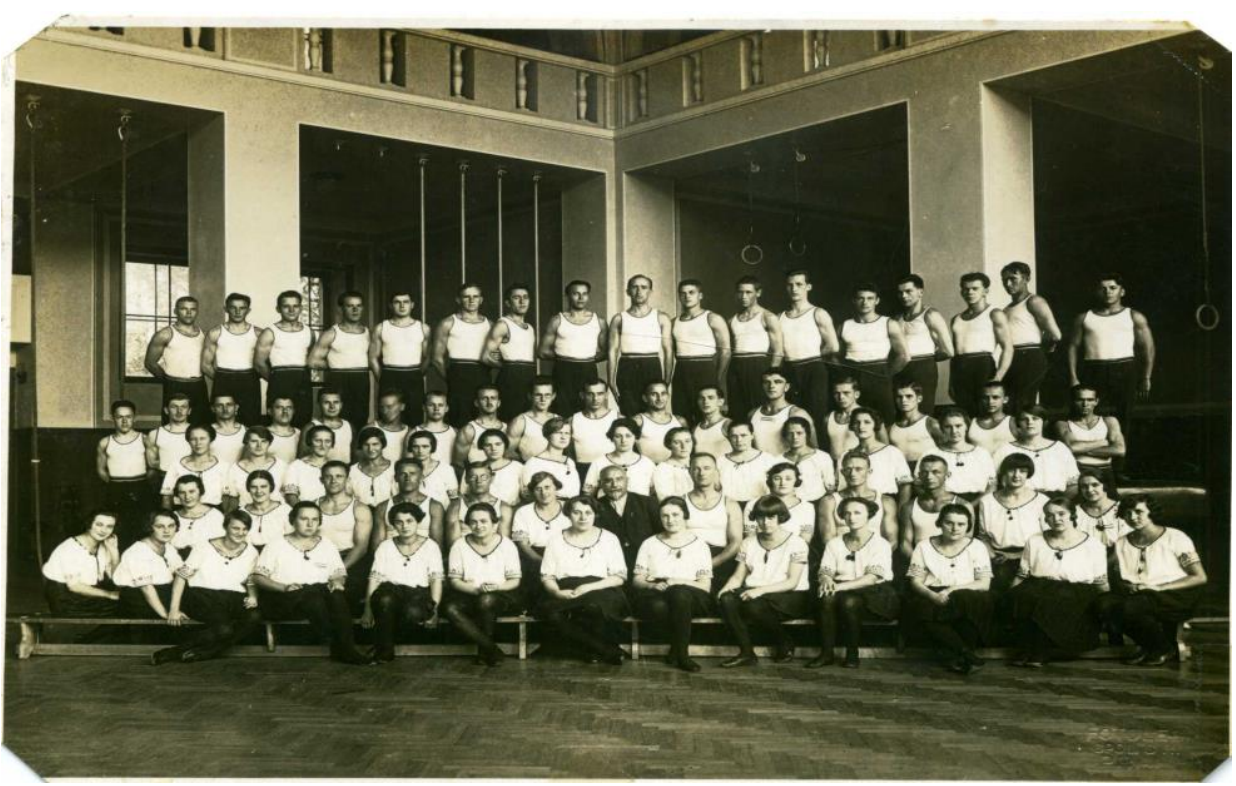

Picture 6: 1928 - As a federal frontman

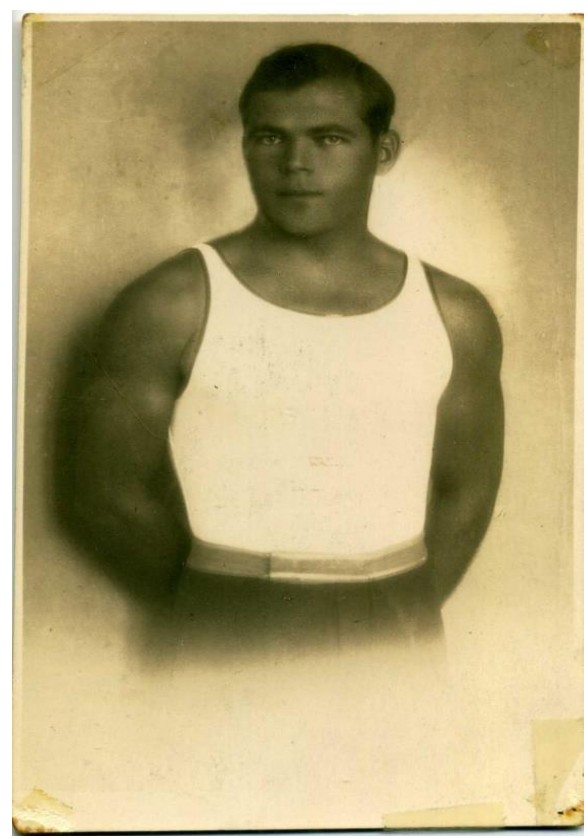


Picture 7: 1929 - Participants of the first federal course for rally exercises for the federal rally on Vidovdan 1930 in Belgrade; R. Ban, sitting, the fifth from the left in the front row.

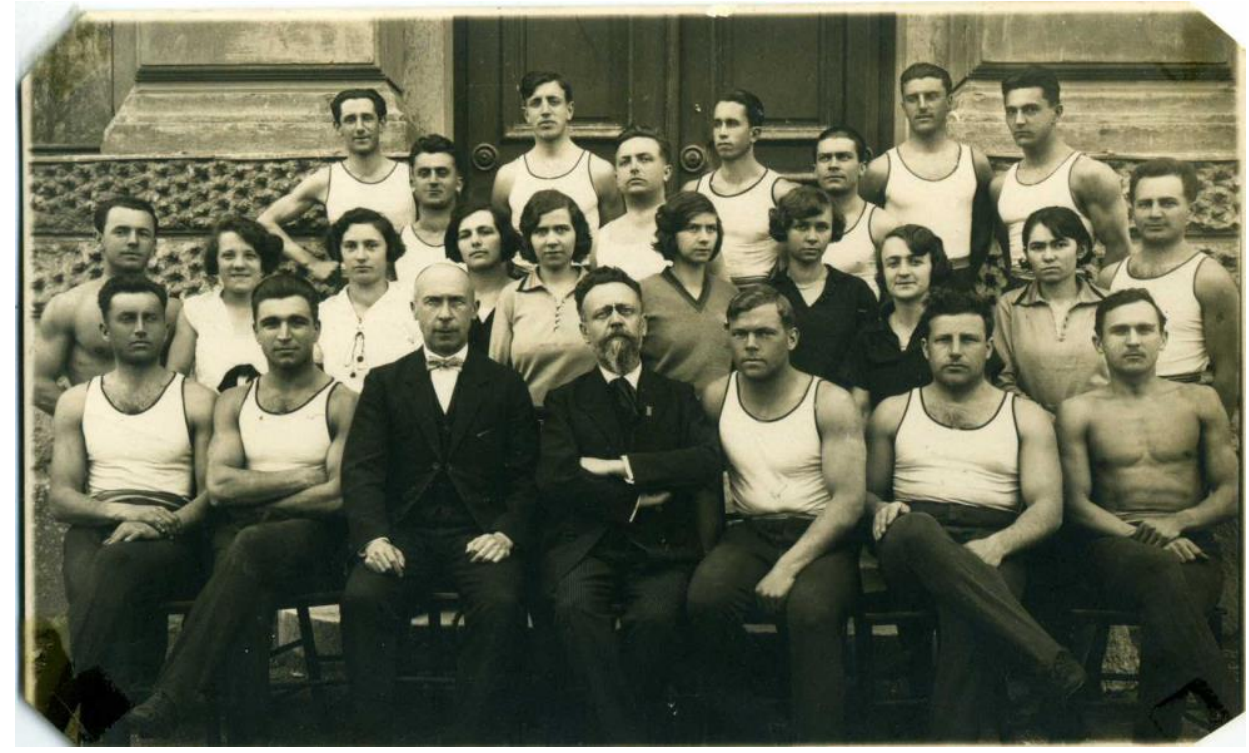

Picture 8: 1930 - The team for the World Gymnastics Championship in Luxembourg. At the end of the preparations in Ljubljana, they gave a public class. All the competitors except R. Ban were from Ljubljana. From the left: Leon Štukelj, Petar Šumi, Anton Malej, R. Ban, Josip Primožič, V. Murnik

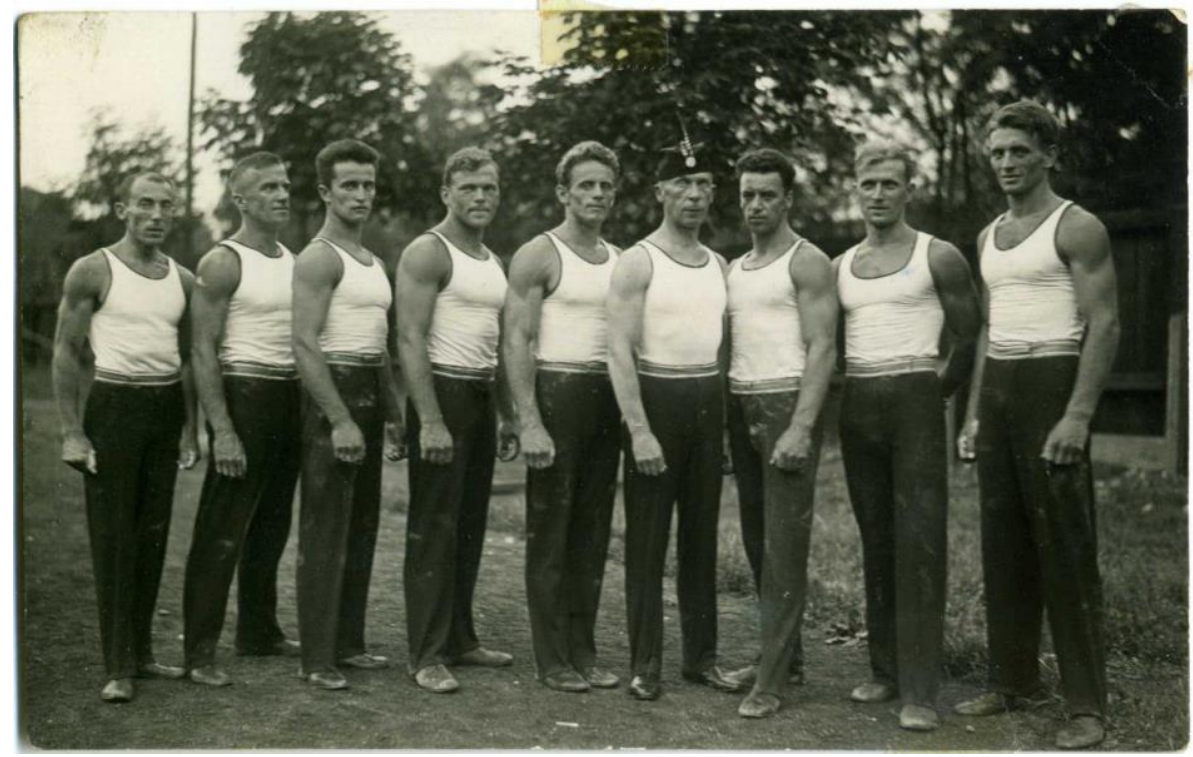


Picture 9: 1930 - The best gymnasts after the competition at the World Cup R. Ban is the fourth from the left.

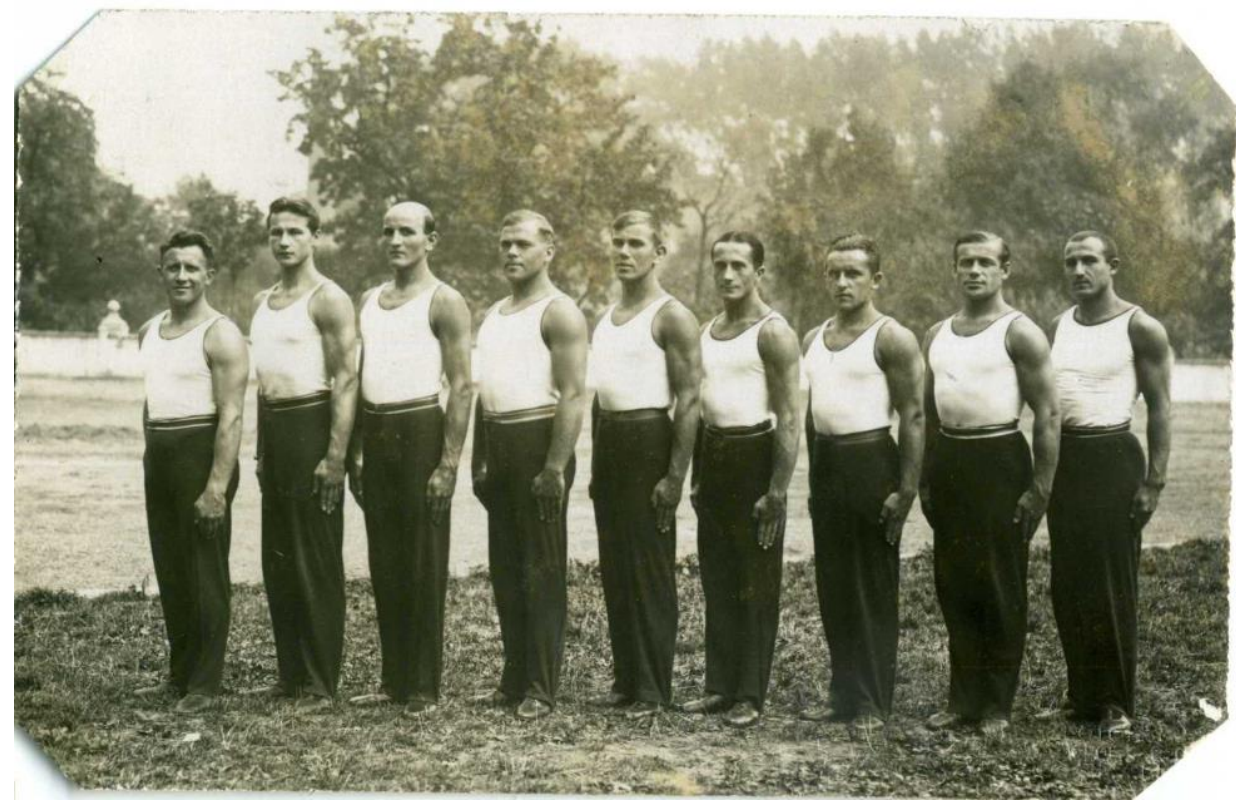

Picture 10: 1931 - Great frontmen course in Zrenjanin; R. Ban, standing, next to the course leader

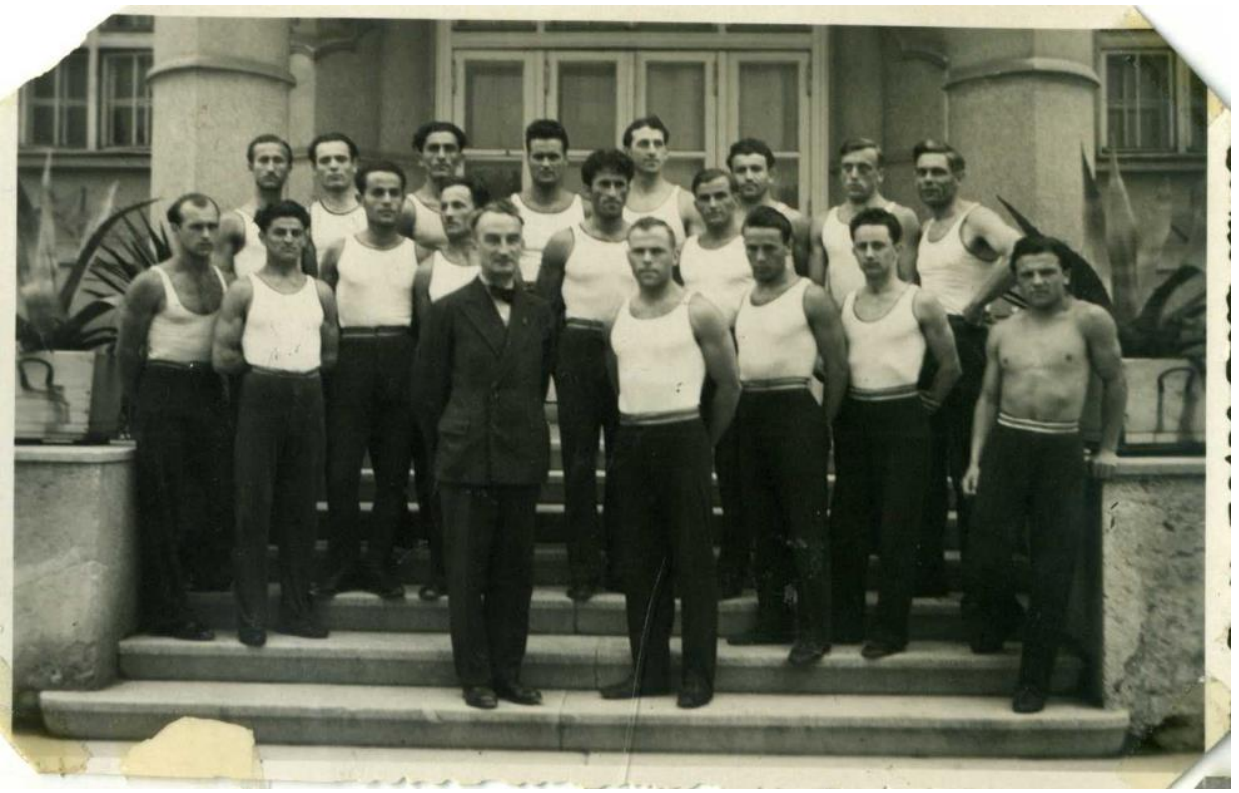


Picture 11: 1933 - In Savska St., near the Theatre in Zagreb; Frane Žic (head of the District of Belgrade), Marijan Boras (head of the administration of the District of Rijeka), Franc Locki (head of the administration of Split) and R. Ban as the federal frontmen; going to the meeting about the federal rally in Zagreb in 1934. Ban R. is the third from the left.

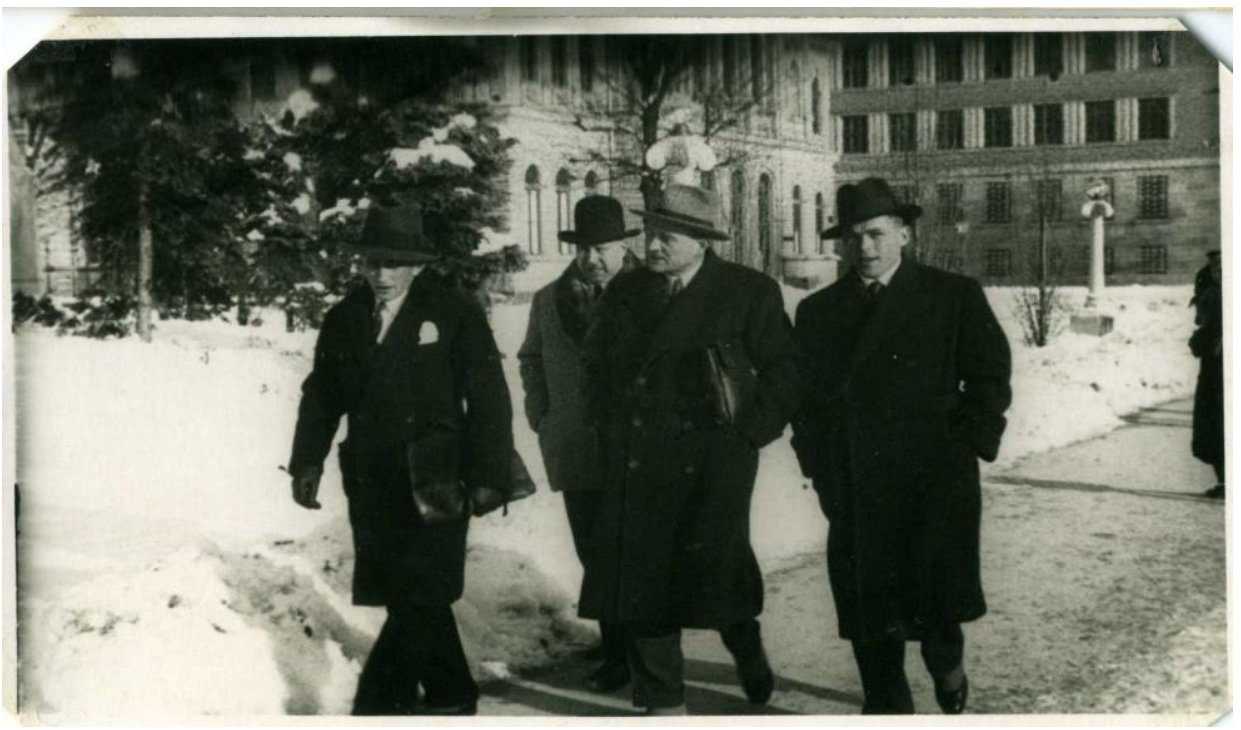

Picture 12: 1950 World Gymnastics Championships in Basel; R Ban at the beginning of the line, the first from the left

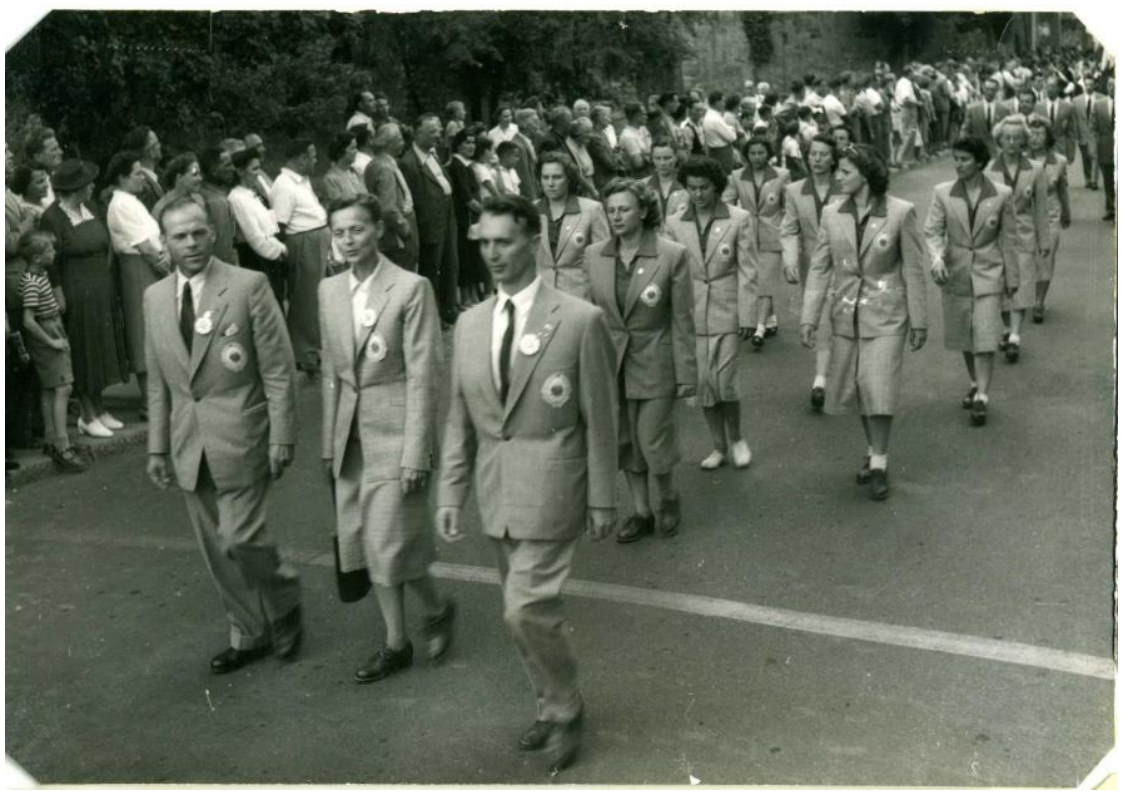


Picture 13: KUNNIAKIRJA - Diploma of the team leader in 1952 - Olympics

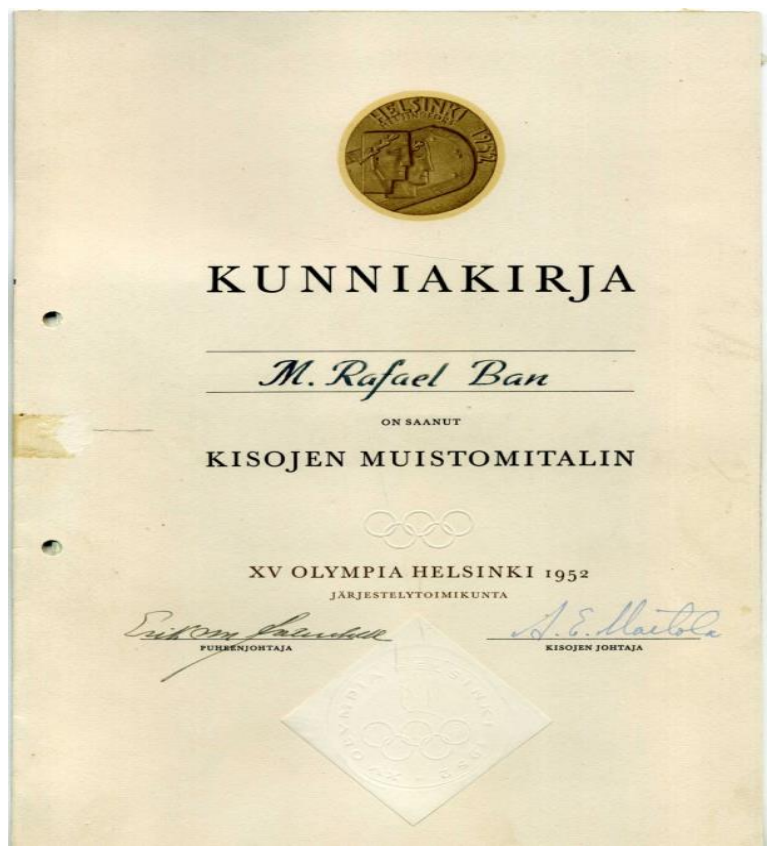

Picture 14: Identity card of the participants in the 1952 Olympics

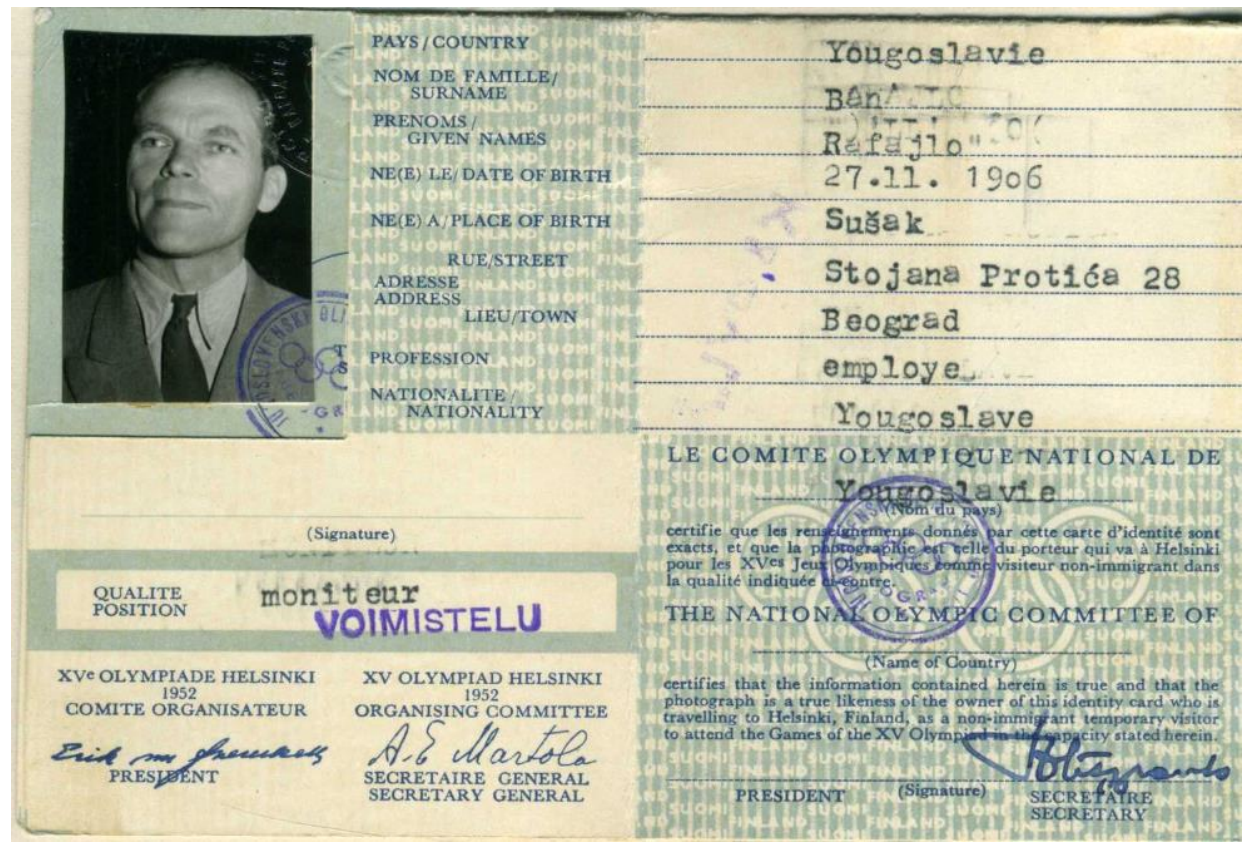


Picture 15: "With Marshal Tito", the exercise with 515 soldiers was designed and prepared by R. Ban; a picture from 1966, with a group of participants (he designed the exercise for the May 25 rally with the JNA five times).

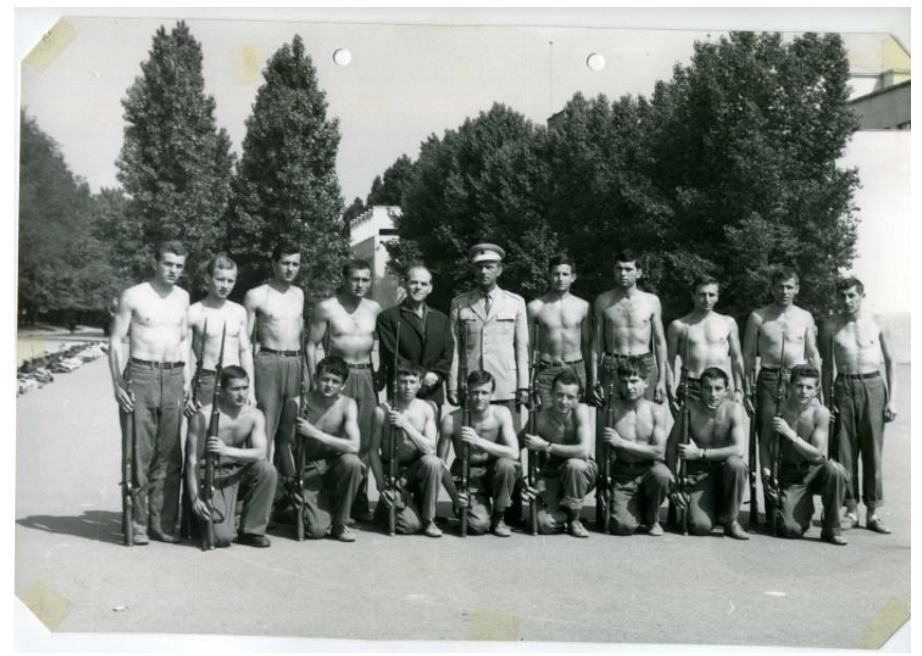

Picture 16: Retirement of Jelka Ban in 1967. Jelka Ban was the wife of R. Ban. She was born in Bosut near Sremska Mitrovica in 1906. In 1929 she became the head of the Sokol Association of Sremska Mitrovica. In 1932 she became a federal frontman and a member of the expert board of the Sokol Association, where she stayed until 1941. From 1946 to 1948 she worked at the Physical Culture Association of Yugoslavia, from 1948 to 1952 in the Gymnastics Association of Yugoslavia and from 1952 until her retirement, in STV Partizan Yugoslavia as a secretary.

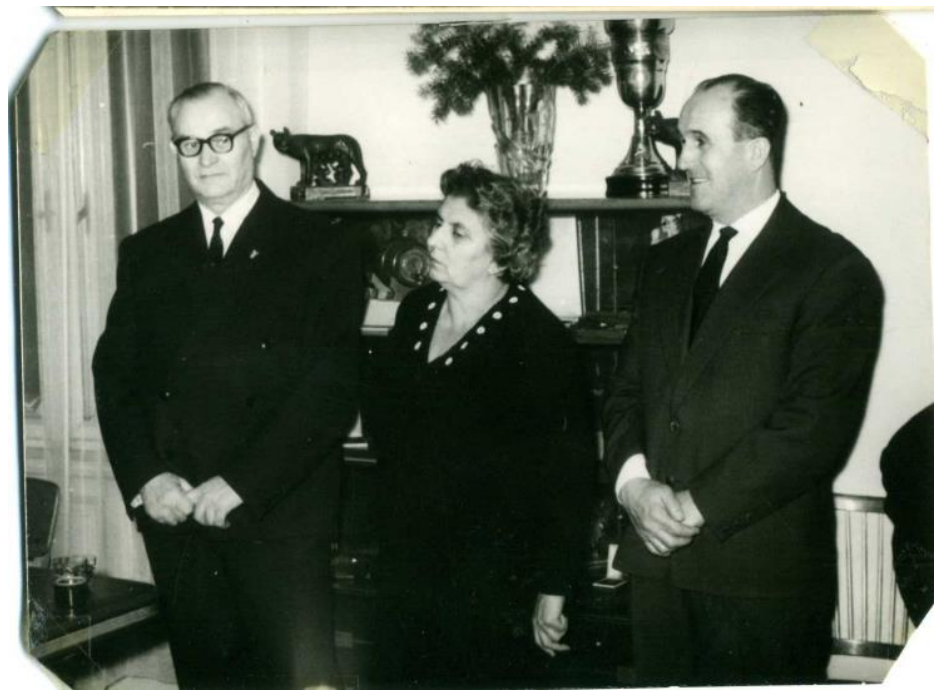




\section{PROF. DR. DUŠANKA BAN \\ (1949-2000)}




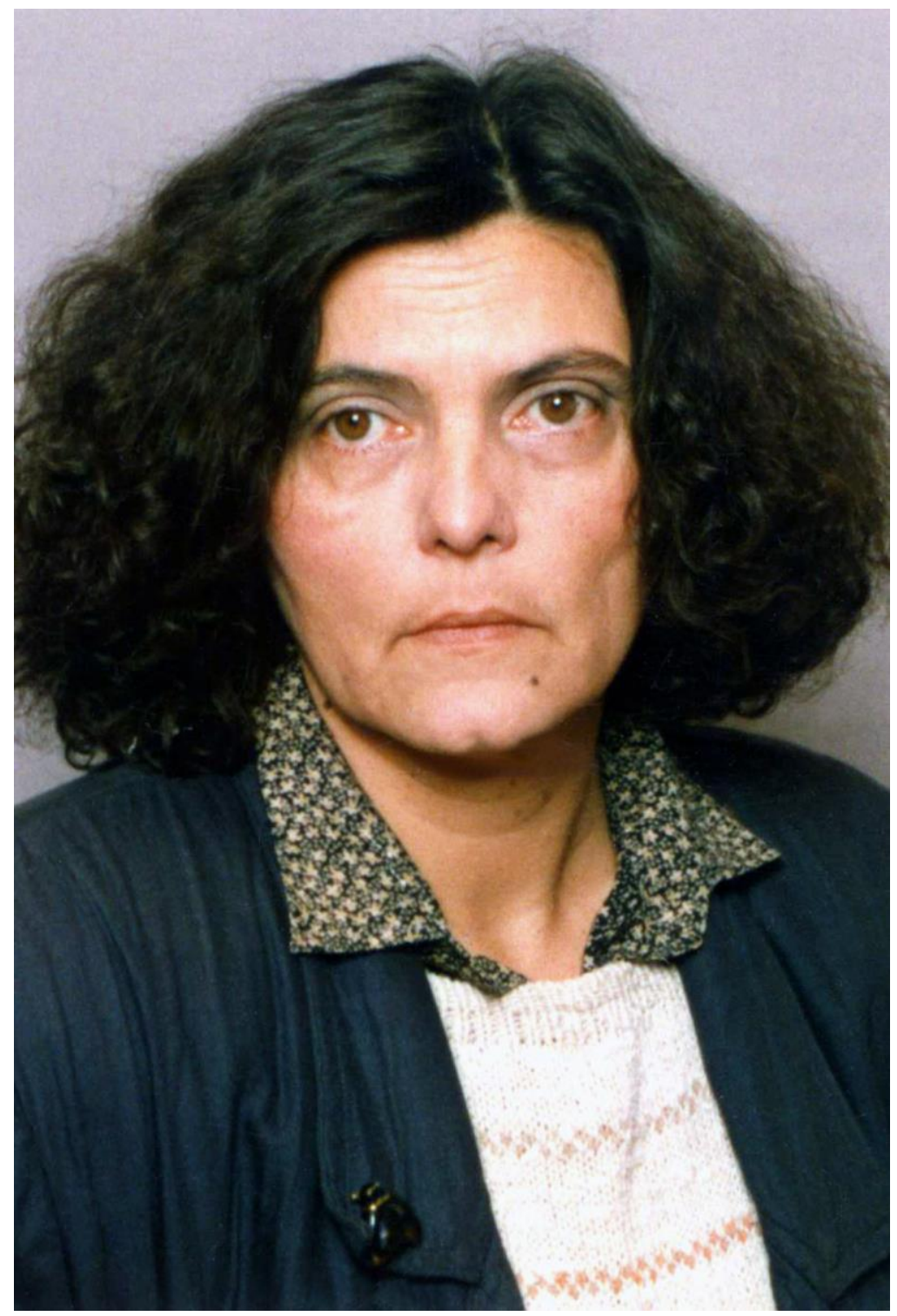

\section{GIANT OF PHYSICAL CULTURE}


Suddenly, on July 28, 2000, the heart of the greatest giant of sports informatics in the field of physical culture in our country and in the world stopped beating. The heart of a great expert, great lady, selfless co-worker, beloved friend, athlete, a world figure in the field of physical culture, gentle wife - stopped beating.

Dr. Dušanka Ban was born in 1949 in Belgrade to mother Jelena and father Rafael, well-known Yugoslav sports experts. She graduated in 1972 from the Faculty of Physical Education (FFK), University of Belgrade (the first in her generation, with an average grade of 9.20), with a focus on sports recreation (school year 1971/72). Her professional title is a professor of physical education and professor, graduate organizer of sports recreation. At the same faculty, she obtained a master's (1978) and doctoral (1986) degree. The topics of both dissertations were in information science, an applied area of physical culture. She was elected a research fellow at FFK in Belgrade in 1989, and a research associate in 1998.

Dr. Dušanka Ban was added to the "Register of Researchers and Automated Records" of the Ministry of Science and Technology of the Republic of Serbia for the first time in 1990, and again in 1993.

She completed the International Lehergange fuerVorlaeser der wissenschaftlichen (International seminar for teachers of scientific information in sports), Warsaw in 1973, organized by the Association for Sports Information and Akademia Wychowzneania Fych).

She completed two Yugoslav seminars for sports documentation specialists in Portorož in 1973 and Novi Sad in 1984, organized by the Yugoslav Sports InDoc Community. As a scholarship holder of the University of Zagreb, she completed two international courses organized by the Interuniversity Centre for Postgraduate Studies in Dubrovnik: "Technology, Education and Research in Library and Information Science", 1984 and "Research Methods in Library and Information Science", 1986.

Dr. Ban spoke English, German and Russian.

\section{EMPLOYMENT}

From 1972 to 1983 she was employed at the Yugoslav Institute for Physical Culture and Sports Medicine.

From 1980, at the Sports InDoc Centre, as a documentalist in the status of independent researcher, she headed the documentation and literature departments, organized international information and documentation cooperation and worked on creating an information system for physical culture. 
She did information research, as well as research on sports recreation and the organization of physical culture.

As the editor of the reference bulletin "Information in the field of physical culture", she published 20 volumes with 3,400 summaries and 764 bibliographic items (in the period 1972-1981). As the editor of the national "Bibliography of Physical Culture", she prepared 10 volumes (Nos. 9-19) with 4,565 annotations; edited other publications and prepared information based on statistical and factual data.

From 1984 to 1986, she ran the Library and Information Centre at the Faculty of Physical Education, University of Zagreb, and participated in teaching and research.

The most important achievements in this position are: initiating information research at the faculty (two multi-year projects); publishing Library and Information Centre's circulars (18 issues in three volumes; connecting of libraries of physical education faculties in the country; collecting and publishing materials for the first bibliography of master's and doctoral dissertations in physical culture; participation in international bibliographies "Youth Sport", "Sport and Peace", technological literature - "World Sports Periodicals Index".

From 1987 she returned to the Yugoslav Institute for Physical Culture and Sports Medicine in Belgrade (JZFKMS) with the title of research fellow, and since 1998 with the title of research associate on documentation of scientific literature and international cooperation.

As part of her research work, she conducted several projects independently in the field of organizing physical culture and sports informatics. She led the building of the Information System of Physical Culture of Serbia IFIS, which was realized in cooperation with 4 institutions: JZFKMS, the Republic Association of Physical Culture of Serbia, the Association of Organizations for Physical Culture of Serbia and the Faculty of Physical Education of the University of Belgrade. She collaborated with the International Sports Literature Database (at the Sport Information Resource Centre, Ottawa, Canada): she worked at the Executive Committee and expert commissions (for Thesaurus, within cooperation of the SFRY with the European Council and was a member of the Committee for Sports Information Science.

\section{Expert and scientific work}

Dr. Dušanka Ban collaborated in 36 scientific and development-research projects, of which she was the holder in 22. She participated in designing of six information systems and several software packages.

The outstanding projects in which she participated was the five-year research (1991-95) from the then current five-year programme of the Ministry of Science 
and Technology ("The Impact of Urbanization on Spatial and Economic Development of Serbia", Faculty of Architecture, University of Belgrade).

Dr. Dušanka Ban published over 250 research papers, more than 70 small InDoc articles in the Fizička kultura Journal (Physical Culture) and about twenty popular articles in Rekreacija (Recreation). One of the creators of the new laws on sports in Montenegro and Serbia

\section{Participation in conferences}

Dr. Dušanka Ban participated in numerous scientific conferences in the country and abroad with invited lectures, reports, announcements or as an observer, mostly in the field of scientific information, information science, InDoc activity, organization of physical culture, propaganda and sports recreation.

Important meetings in the country and abroad (selection):

- Summer School of Physical Education Teachers of Yugoslavia (6 of 10, 1988-1991);

- Summer School of the Republic of Serbia from 1991-99

- Congresses of Physical Culture Pedagogues of Yugoslavia (all 4, 1981-90);

- "FIS komunikacija” (Phys-Communication), Niš (all meetings from 1992);

- Yugoslav conferences on sports recreation (4);

- Yugoslav conferences "Sport and Science" (held from 1981-83)

- Yugoslav Conference "Physical Culture in the Media" (1986);

- Scientific meetings of the Faculties of Physical Education in Belgrade and Novi Sad

- $\quad$ TV World “Sport for All” Congress, Varna 1992;

- Yugoslav seminars for sports documenlists (both 1974-76);

- International Congresses of Sports Informatics (8 out of 9 held in 1973-1993);

- Assembly of the International Association for Sports Information IASI ( 8 of 9 );

- $\quad$ Meetings of the IASI Executive Committee (18);

- Working sessions of IASI expert commissions (over 15);

- Multifunctional conference "Technical Social Aspects of Information and Communication" (4);

- Yugoslav congresses and seminars for informatics and information science (7); 
- Congresses and professional conferences of librarians (6)

By invitation, she participated in several round tables, e.g., on the dissemination of local scientific information abroad at the Multifunctional Conference "Technical and Social Aspects of Information and Communication" (Zagreb, 1978); "Professional and Self-Management Knowledge of Workers in Education", organized by the Belgrade journal Nastava i vaspitanje (Teaching and Education) (Kraljevo 1981); "Sport and Science", organized by the Belgrade magazine Ilustrovana politika, (Belgrade, 1987); "School Sport" (Sombor, 1992); "Women and Sport" (Kopaonik, 1999), etc.

She led the Round Table "Methodological Culture" of the VIII Summer School of Physical Education Teachers of Yugoslavia 1988, Šibenik 1988.

\section{Participation in the organization of meetings}

As a member of the Executive Committee of the International Association for Sport Information - IASI, organized a session of the Executive Committee in Yugoslavia, Belgrade in 1981

As a member of the Organizing Committee and the Programme-Scientific and Editorial Board, prepared the Yugoslav conference "Physical Culture in the Media", Ohrid 1986 (organized by the associations of physical education teachers of Macedonia and Yugoslavia); participated in the organization of two Yugoslav conferences "Sport and Informatics", Association for Physical Culture of Yugoslavia, as the holder of the main project, Belgrade 1981; a collaborator on one of the three main projects, Split 1983)

Organized three Yugoslav meetings of the Board of Professional Periodical Editors and Publishers of Sports Literature (Split, 1983, Zagreb, 1984 and Ohrid 1986), as well as three Yugoslav meetings of sports librarians (Kranjska Gora, 1985, Ohrid 1986, and Novi Sad 1987)

Participated in the realization of two Yugoslav seminars for sports documentalists of the Yugoslav Sports InDoc Community (Portorož 1974, Novi Sad 1975), and in the preparation of several conferences within the Community

Member of the initiative group for the scientific conference "FIS komunikacije" (PHYS Communications), organized by the Department of Physical Education of the Faculty of Philosophy in Nišs, starting from 1992

As a member of the programme commission, participated in the revival and organization of the Summer School of Physical Education Teachers in Sombor 1994 


\section{Work in the editorial boards of professional and scientific journals}

From 1974, she continuously edited the "InDoc Column" in the Fizička kultura Journal, Belgrade; in the period 1974-94, published 641 articles and, in the same journal, started and ran sections for sports science, terminology, patents of sports equipment and props, the application of computers in physical culture.

From 1984 to 1990 she was a member of the editorial board of the scientific journal Kineziologija (Kinesiology), Zagreb (Association of Physical Education Teachers of Yugoslavia, published by the Faculty of Physical Education, University of Zagreb).

She was a member of the Editorial Board (from 1973-75) and the Council (1975-82) of the magazine Rekreacija (Recreation), Belgrade, (published by the Republic Association Partizan, Serbia)

She worked as a reviewer at the Informatika Journal, Belgrade (published by the Yugoslav Centre for Technical and Scientific Documentation) from 1985 to 1988; and Informatologija Yugoslavica Journal (published by the Institute of Information Sciences in Zagreb) from 1987-89.

In April 1988, she was appointed to the Programme Council of RTV Belgrade for physical culture programmes, as a delegate of the Yugoslav Institute for Physical Culture and Sports Medicine.

\section{Activity in teaching and in-service training}

While she work at the Faculty of Physical Education, University of Zagreb, she participated in teaching at the Systematic Kinesiology Course and mentored several graduate theses.

As a lecturer by invitation, she gave lectures in information science at postgraduate studies:

- Faculty of Physical Education, University of Novi Sad Organization of Physical Education, 1983-87

- $\quad$ Faculty of Physical Education, University of Belgrade - Recreation Department, 1988, and Physical Education Department, 1994 and 1995.

She gave lectures on sports recreation to students of the Faculty of Physical Education in Belgrade (1973), and Faculty of Architecture in Belgrade on the subject of Urban Functions (1981).

At the Seminar for Physical Education Teachers from Libya, Belgrade 1975, (organized by the Yugoslav Institute for Physical Culture and Sports Medicine), she taught the application of information and documentation activities. 
She gave lectures on InDoc activity at:

- the First Conference of Recreation Experts, Pančevo 1973,

- the Conference of Partizan, Yugoslavia, "Information and Propaganda in Sports Recreation" (Tuheljske Toplice 1982);

- two conferences of the Association for Physical Culture of Yugoslavia on the preparation of top athletes (Belgrade, 1977, Aranđelovac, 1978)

- the "Organization of Physical Culture" Seminar (Subotica, 1980), organized by SOFK Subotica (Federation of Physical Education Organizations);

- the Yugoslav seminar of the Weightlifting Association (Belgrade, 1994);

- the Olympic Solidarity Seminar, the Weightlifting Federation (Belgrade, 1995);

- Seminars for sports journalists (Yugoslav Institute of Journalism, 1978, 1989; and the /Spiker [Speaker] Agency, 1994).

In 1987, she mentored the internship of a documentalist at the Institute for Physical Culture.

In 1995, she was elected to the commission for evaluation of a doctoral dissertation project.

\section{Membership in and cooperation with professional and scientific associations}

She was a member of the International Association for Sports Information IASI from 1973. In three terms (from 1974-1988) she was elected a member of the Executive Committee of this Association, and in 1989 she was appointed an advisor. At the IASI Assembly in 1988 in Rome, she was elected an Honorary Member.

In the period 1973-83 she collaborated with the IASI Thesaurus Commission on the development of an international multilingual physical culture thesaurus; from 1983, worked at the IASI Commission Information Sources, which compiles international bibliographies, indices of primary and secondary periodicals; from 1981 to 1989, was active in the IASI Coordinating Committee, which brings together national InDoc Centres and the IASI Sports Database, (headquarters at SIRC, Ottawa, Canada).

In April 1988, the Federation of Physical Culture of Yugoslavia elected Dušanka Ban as the Yugoslav representative in the Council of Europe - Committee of 
Experts on Sports Information, in which she actively cooperated until the FRY, due to international sanctions, was omitted from membership in this body.

In the Association of Special Libraries of the SR Serbia, she was a member of the Executive Board, from the founding of the Association, in 1980, to 1984. She was a member of the Society for Informatics of Serbia from 1978.

For several years, she cooperated in the Propaganda Commission of the Republic Association Partizan, Serbia. She was the president of the Commission for Propaganda and Information Activity of the Association for Sports Recreation of the FRY (from 1992 to 1994, when she resigned). In 1987, she was appointed to the Professional Team of the Yugoslav Sports Association Partizan. She was a member of the presidency of the Gymnastics Federation of Yugoslavia (from 1993) and the Executive Board of the Sport for All Association, Belgrade (from 1993).

At the Faculty of Physical Education in Zagreb, she worked in the Terminology Commission and the Publishing Commission.

At the Yugoslav Institute for Physical Culture and Sports Medicine (JZFKMS), she was a member of the Expert Council (from 1987).

She was a personal member of the Federation International du Education Physique - FIEP, as long as her income allowed her to pay foreign currency membership fees.

\section{Sports experience}

She was actively involved in rhythmic gymnastics (she competed up to the level of the state championship 1964-67), in which she also acted as a republic judge and practiced autonomous diving (independent diver and instructor 196586). For several years, she led the categories of pioneers, youth and members of the Association Partizan 6 in Belgrade.

\section{Absolute authority in her profession}

Professional and scientific contribution of Prof. Dr. Dušanka Ban is truly a cornerstone of Yugoslav and world sports informatics and her imposing work would be the theoretical backbone of the future development of sports informatics in physical culture. At the commemorative session held on January 8, 2000, prof. Dr. Sergije Lukač said: "Without the work of our Dušanka, Yugoslav sport would be without essential information, without self-awareness and without a clear vision of its future and rational ideas in the strategy of development of physical culture and sport. Our Dušanka possessed a miraculous balance in parallel with all relevant factors of sports development and at the same time creative organizational bases of informatics in sports. ...Dušanka Ban, a woman always full of the joys of life, responsible optimism, of human breadth, diligence 
confirmed by strict adherence to deadlines, was an example of a builder of physical culture and sport. She carried the goodness of human composure, and with her appearance, her work, she reminded us of the dignity, kindness of those who believe in sports and its essential humanity and educativeness. ...She was an absolute authority in her profession, without discussion recognized in the world and in our country. ...By its quantity and veracity, her bibliography and the work she produced, falls into the category of the most fruitful. ...The family, her friends, Yugoslav sports are poorer for a wonderful person, an important factor of progressive development. And, at the end, let's say what highlanders would say in honour of the departed "A good reason had she to be alive!"

Prof. Dr. Dušanka Ban wrote her last scientific work / 256./ "Sports Informatics as a School Subject" for the $11^{\text {th }}$ IASI WORD CONGRESS / LAUSANNE / April 25 - 27, 2001. The paper was read at the Congress and all members of the Congress received a copy of "Informational and Organizational Elements of Sport", a textbook for students of the Sports Academy in Belgrade, for the subject of Informational and Organizational Elements of Sport. In memory of life with prof. Dr. Dušanka Ban, the publisher of the textbook dedicated to the participants of the Congress in Lausanne was prof. Dr. Vladimir Kebin.

By the decision of the Teaching Council of the Sports Academy in Belgrade, the Sports Academy established a professional library - "National Sports Library Dr. Dušanka Ban".

A deep bow to the PERSONALITY, work, activity, enthusiasm, love and knowledge of Prof. Dr. Dušanka Ban

Glory to you and thank you my and our Duška.

\section{Information and documentation activity}

The Institute began its information and documentation activity in 1956. The first associates in this job were Mladen Milutinović, Olga Acić, Dragan Maršićević and Mirjana Veljković. Later, the Information and Documentation Department of the Institute grew into a specialized service (Sports INDOK Centre). This activity includes documenting statistical data, sports results and professional literature, preparation of information materials, international cooperation, research and improvement of InDoc activities and library work. The InDoc activity is practically divided into documentation of statistical data, documentation of sports results and documentation of professional literature.

The InDoc activity is carried out within the tasks for the Association of Physical Culture of Yugoslavia, i.e., republic / provincial SOFK. It is carried out in the form of three basic tasks: "Programme of index activities of interest to the Republic", "Selection of translations from foreign literature" and "Methods of implementation 
and financing of information and documentation programme in the field of physical culture".

Since its foundation, the Institute has collected documentation in the field of physical culture. Almost all data in this area are collected and specific information is prepared for socio-political communities, interest communities of physical culture, and above all for social organizations of physical culture (SOFK Yugoslavia, SOFK Serbia, later the Sports Federation of Serbia, etc.), important for their activity.

Through the monthly bulletin - "Information in the Field of Physical Culture", as the first bulletin that provided materials on the state of organizations, the results of physical culture in the country and abroad, data important for the further development of physical culture were obtained.

At the suggestion of the Institute, the Federal Bureau of Statistics in its statistical research also processed the field of physical culture, which provided the documentation necessary for the preparation of medium-term development plans and a number of other documents important for further progress of physical culture in Yugoslavia, primarily in Serbia.

It began publishing a bibliography of annual editions by Yugoslav authors. From the very beginning, the Institute translated selected professional material from foreign languages, which, after an appropriate review, was multiplied and delivered to all professionals in Serbia and Yugoslavia.

At the initiative of the Institute, the Yugoslav Sports and InDoc Community was established, consisting of providers and users of services in the information and documentation activities: the Institute's Sport InDoc Centre, libraries, institutions, republic SOFK and other bodies for physical culture. Cooperation was established with the International Association for Sports Information (IASI-ICPE), by including documentation cards of Yugoslav professional literature in international sports documentation. Cooperation was also achieved at the international multilingual sports thesaurus in the Thesaurus Commission. Dušanka Ban, an associate of the Institute, as an active member of these organizations, participated in projects, congresses and assemblies of these associations.

In the period of 50 years, a large number of titles of serial primary and secondary information publications in the field of physical culture, individual information publications, books, studies and research were published. In the first 25 years alone, during the period of intensive work of the Institute, 30 titles of serial primary and secondary information in the field of physical culture, 20 individual information publications, 30 books, 33 studies and 17 researches were published, the total volume was 3,708 author's sheets or 55,620 pages. In recent years, this huge publishing venture has been significantly reduced for a number of objective reasons, primarily the lack of financial resources that have affected the overall work of the Institute. 
The Institute is also developing a significant publishing activity, which in one period reached 19 editions a year, in the form of monographs and periodical publications, the volume of which amounts to several hundred author's sheets of professional literature.

Various statistical data on physical culture in the SFR Yugoslavia and SR Serbia without the provinces were collected and published in the form of publications, yearbooks and periodic volumes.

The organization and state of physical culture was monitored, plans for its development and their implementation, financing of physical culture, including income of physical culture from games of chance (lotto and the pools), training of professional staff for physical culture, physical education classes in schools and facilities for physical culture.

This statistical information was most often issued once a year in different shorter or longer periods of time and in different circulations (up to 500 copies) and distributed to users. Some of the statistical information, as individual publications, included other topics such as statistics of higher social bodies for physical culture, the state of physical culture in cities, problems of physical culture propaganda, the delegate structure of SIZ (Self-Governing Community of Interest) of physical culture bodies in 100 municipalities of the SR Serbia without provinces, factors that slow down the development of physical culture in the SR Serbia without provinces and information on football. These jobs were in charge of Dragan Maršićević, Mladen Milutinović, Darinka Vidaković, Mirjana Veljković, Olga Acić, Dušanka Ban and Zoran Jovanović.

Factual information on sports results of elite athletes from Yugoslavia, Serbia with and without provinces, then Serbia and Montenegro, were published regularly from 1956 (except 1963; 1965; 1972 and 1973). It included the participation of our elite athletes in the Olympic Games, world and European championships. This was in charge of Dragan Maršićević, Mirjana Veljković, Olga Acić, Dušanka Ban, Aleksandra Sanader, Branka Ćirić, Milanka Borovićanin and Jelena Ivanović.

Local and foreign professional literature was processed and the results were given in the following periodical publications:

"Bibliography of Physical Culture"

"Selection from Foreign Professional Literature" - "Sports Practice"

"Information on the Acquired and Translated Literature in Physical Education Institutions"

"Modern Training"

"Physical Education Information Bulletin"

"Physical Culture Congresses, Symposia, Conferences" 
"Selection of Articles from Foreign Literature"

"Information in the Field of Physical Culture"

Permanent editors of these publications were Dragan Maršićević, Dušanka Ban and Srdjan Savić, and two issues of the "Bibliography of Physical Culture" were edited by Vlastimir Despotović.

The majority of professional articles were translated by Časlav Krsmanović, Ileana Ćosić, Ljiljana Mladenović and Klara Sentđerđi, from the Institute, and a large number of translators from different languages, external associates of the Institute, also collaborated. The two books were translated by the associate of the Institute, Srđan Savić.

The Institute's Sport INDOK Centre organized, or initiated the organization of a series of professional meetings: conferences on the organization of the statistics service, conference of the Yugoslav Sports InDoc Community and seminars for documentalists with eminent foreign lecturers in this field. The associates of the Institute participated in the work of international congresses of sports information and the International Association for Sports Information, attended seminars for documentalists in sports, and cooperated in the thesaurus commissions of the International Association for Sports Information.

\section{Dr. Dušanka Ban - a symbol for information activity}

The associate of the Institute Dušanka Ban was a member of the International Association for Sports Information - IASI from 1973 and she had been making a notable contribution until her untimely death in 2000. In three terms (from 19741988), she was elected a member of the Executive Committee of this Association, and in 1989, was appointed an advisor. At the IASI Assembly in 1988 in Rome, she was elected a lifelong Honorary Member. In the period 1973-83, she collaborated with the IASI Thesaurus Commission on the development of an international multilingual physical culture thesaurus; from 1983, worked at the IASI Commission Information Sources, compiling international bibliographies, indices of primary and secondary periodicals; from 1981 to 1989 , was active in the IASI Coordinating Committee, that brings together national InDoc Centres, members of the IASI International Sport Database, headquarters at SIRC, Ottawa, Canada).

In April 1988, the Federation of Physical Culture of Yugoslavia elected Dušanka Ban as the Yugoslav representative in the Council of Europe - Committee of Experts on Sports Information, in which she had actively cooperated until the FRY, due to international sanctions, was omitted from membership in this body.

In the past period, the Institute's InDoc associates participated in the work of a number of local conferences in the field of physical culture and sports information.

The projects of the Information System of Physical Culture (Dragan Maršićević, Dušanka Ban) had been made on several occasions, but due to the lack of 
necessary conditions, they were not realized. Activities on the establishment of information and documentation activities in the sports system of the Republic of Serbia were restarted in 2005, according to the project of the external associate Dr. Predrag Gavrilović. In these activities, the expert team of the Institute consisted of: Branislav Milišić, Jelena Ivanović, Tatjana Milenković, Predrag Bićanin and Biljana Marić-Nikolić.

\section{Information and documentation activity}

Local and foreign professional literature was processed and the results were given in the following periodical publications:

"Bibliography of Physical Culture"

"Selection from Foreign Professional Literature" - "Sports Practice"

"Information on the Acquired and Translated Literature in Physical Education Institutions"

"Modern Training"

"Physical Education Information Bulletin"

"Physical Culture Congresses, Symposia, Conferences"

"Selection of Articles from Foreign Literature"

"Information in the Field of Physical Culture

Permanent editors of these publications were Dragan Maršićević, Dušanka Ban and Srdjan Savić, and two issues of the "Bibliography of Physical Culture" were edited by Vlastimir Despotović.

The majority of professional articles were translated by Časlav Krsmanović, Ileana Ćosić, Ljiljana Mladenović and Klara Sentđerđi, from the Institute, and a large number of translators from different languages, external associates of the Institute, also collaborated. The two books were translated by the associate of the Institute, Srđan Savić.

The Institute's Sport INDOK Centre organized, or initiated the organization of a series of professional meetings: conferences on the organization of the statistics service, conference of the Yugoslav Sports InDoc Community and seminars for documentalists with eminent foreign lecturers in this field. The associates of the Institute participated in the work of international congresses of sports information and the International Association for Sports Information, attended seminars for documentalists in sports, and cooperated in the thesaurus commissions of the International Association for Sports Information. 


\section{PROF. DR SERGIJE LUKAČ}

Copy Copyright (C) 1996-2003 NIN - redakcija@nin.co.yuright (C) 19962003Copyright (C) 1996-2003 NIN - redakcija@nin.co.yu

Last week, Dušanka Ban left us forever. She was the most valuable energy for sports information - equally strongly exposed in the theoretical and research field, as well as in the field of creating an information system in planning the system of physical culture and sport and in achieving the necessary IT basis for practical sport. Without the work of our Dušanka, Yugoslav sport would be without essential information, without self-awareness and without a clear vision of its future and rational ideas in the strategy of development of physical culture and sport. Our Dušanka possessed a miraculous balance in parallel with all relevant factors of sports development and at the same time creative organizational bases of informatics in sports. There was no a phenomenon in the system and life of sport that Dušanka Ban did not record, systematize and present to the professional public. Dušanka Ban, a woman always full of the joys of life, responsible optimism, human breadth, diligence confirmed by strict adherence to deadlines, was an example of a builder of physical culture and sports. She carried the goodness of human composure, and with her appearance, her work, she reminded us of the dignity, kindness of those who believe in sports and its essential humanity and educativeness. By its quantity and veracity, her bibliography and the work she produced, falls into the category of the most fruitful. For generations of students at faculties and academies in Belgrade, Novi Sad and other schools, organizers and coaches, she spoke simply and convincingly about the inevitability of sports information as of a reliable radar in the stormy roar of sports as a global phenomenon. She was an absolute authority in her profession, without discussion recognized in the world and in our country.

4. UDK 796 YUISSN 0350-3828 FIZICKA KULTURA VOL 44-45 $\mathrm{N}^{\circ}$ 1-2 BELGRADE 1990/9 1 PUBLISHER: FACULTY OF PHYSICAL EDUCATION, UNIVERSITY OF BELGRADE

Editor-in-Chief: DR. BOŽO BOKAN

Editor of the Editorial Board: TOMISLAV ACKOVIĆ, MA

DR. DUŠANKA BAN

DR. LJUBIŠA LAZAREVIĆ

DR. ZORICA PETROVIĆ

DR. STANOJE STANOJEVIĆ

DR. JAROSLAVA RADOJEVIĆ 
DR. ĐORĐE RADOVANOVIĆ

DR. NENAD ŽIVANOVIĆ

DR. ŽIVOJIN ŽIVANOVIĆ

Proof reader: SIDA BOGOSAVLJEVIĆ

Translator: VESNA STRIKA

Address of the editorial office and administration: ČASOPIS FIZIČKA KULTURA 11030 Belgrade, 156 Blagoja Parovića St. Phone numbers: 559-089 and 555-487 (ext. 106) PO Box 61 Telefax 555-474 Giro account No. 60812-603- 1947 - Fizička kultura. The Journal is published quarterly. Circulation: 2,000 copies. Annual subscription for institutions 500 dinars, for individuals 400. for students 300 dinars for foreign countries 60 Based on the opinion of the Secretariat for Information of the Republic of Serbia (No. 413-01 495/ 9 1-01) from June 3, 1991, the basic sales tax is paid at the rate of $3 \%$. The journal is published with the financial support of the Republic Fund for Physical Culture of Serbia. By the Decree of the President of the Republic No. 134. from November 7, 1977 on the occasion of the thirtieth anniversary of publishing, and for merits in the development of professional and scientific thought in the field of physical culture and contribution to its advancement was awarded the ORDER OF MERIT FOR THE PEOPLE WITH A SILVER STAR FIZIČKA KULTURA

BAN, Dušanka - Belgrade (D. Ban), 1986. - [183] list, tab. 44, bibliographic items. 131, Annex 3: tables; $30 \mathrm{~cm}$ - FACULTY OF PHYSICAL EDUCATION, University of Belgrade

\section{Sources}

The legal heir of the entire documentation (Biographies and bibliographies) on Raphael and Dušanka Ban is in Prof. Dr. Vladimir Kebin

1. Tomović S.: Aktivnost i prolaznost (Activity and Transience), Teorija, No. 1, 2, Philosophical Society of Serbia, Belgrade, 1977, p.15).

2. Fulgozi A., Radin F.: Stilovi života zagrebačkih srednjoškolaca, Naklada edd, Zagreb, 1982, p. 9).

3. Lukač S.: Copyright (C) 1996-2003 NIN - redakcija@nin.co.yu

4. Завод за спорт и медицину спорта Републике Србије 60 година.: Уредник Иван Митровић, Издавач. Завод за спорт и медицину спорта Републике Србије, ISBN 978-86-7139-033-0 
Picture 1: In conversation with colleagues, the Faculty's Anniversary, Belgrade, 1999

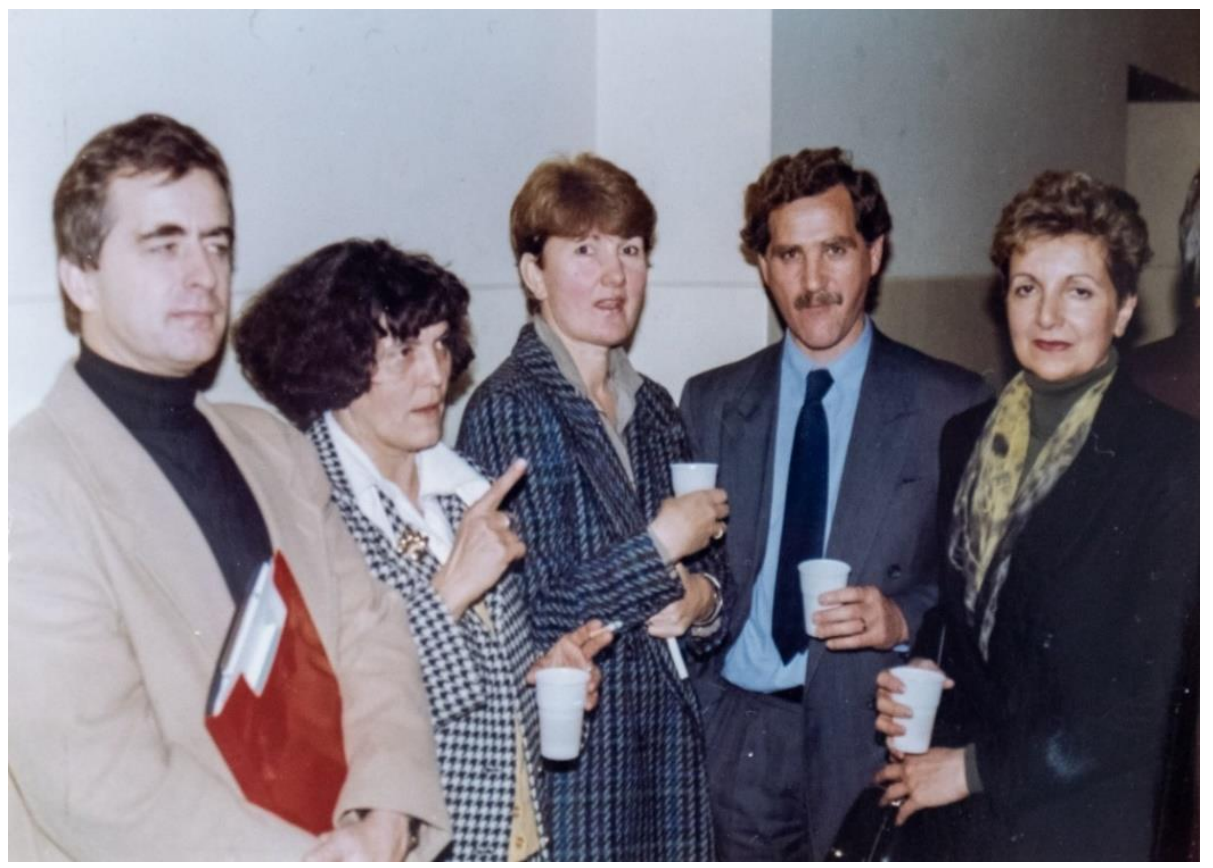

Picture 2: A Lecture at the Sports Academy, Belgrade, 1998

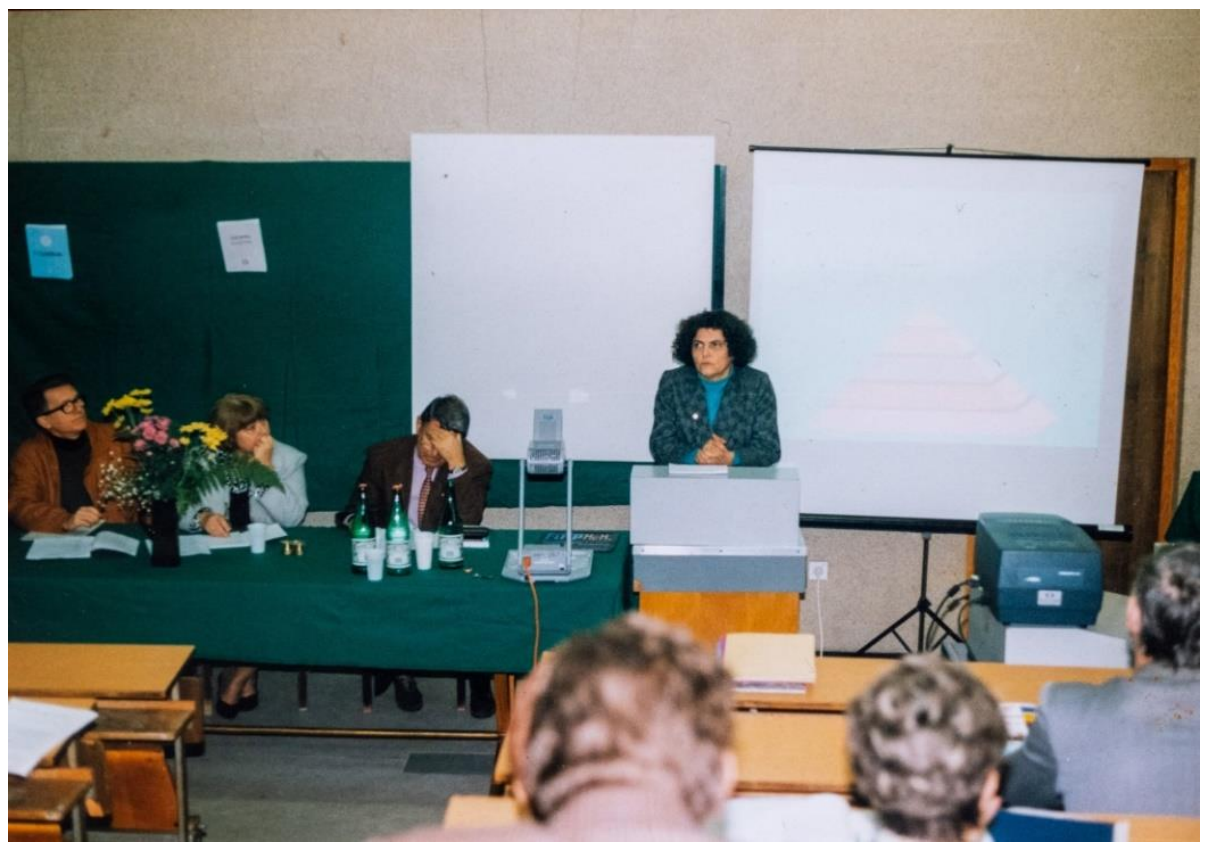


Picture 3: PHYS Communications, Niš, 1997

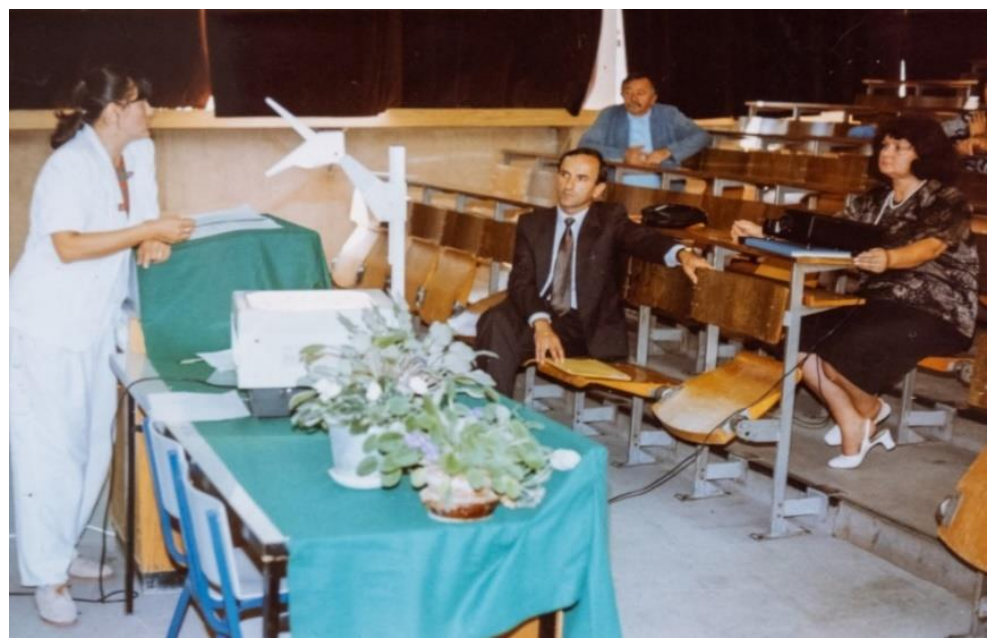

Picture 4: Kopaonik, 1998. (Seminar for physical education teachers in Serbia)

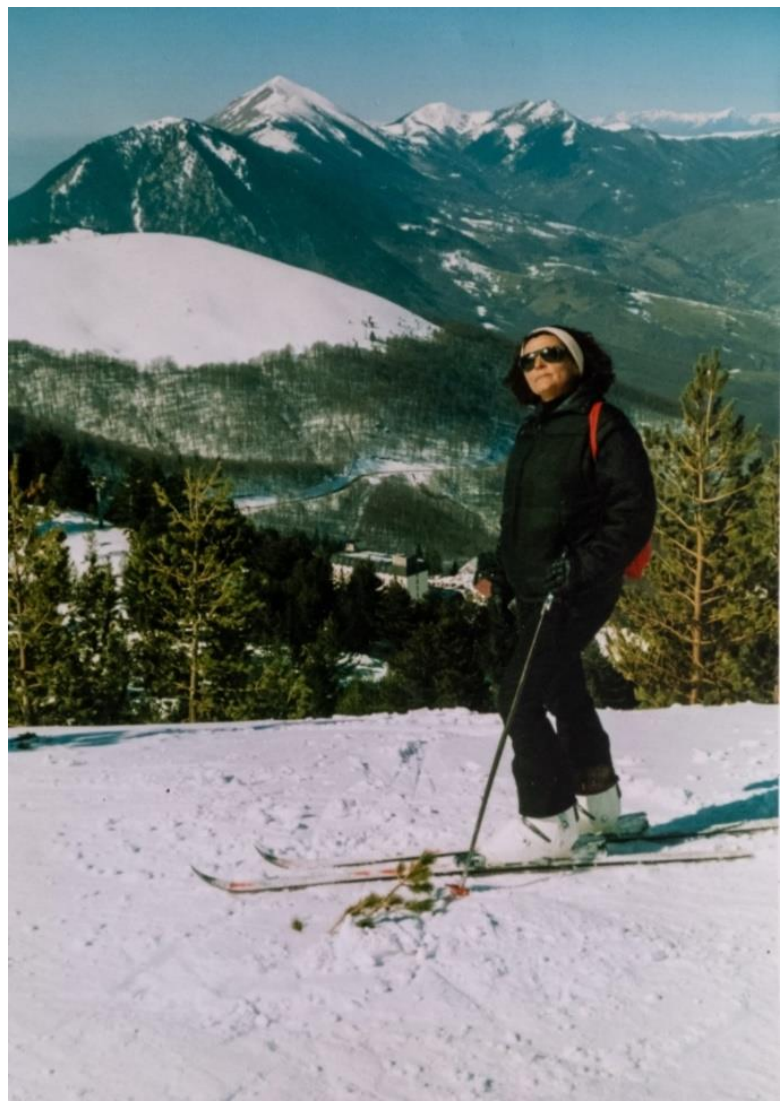




\title{
ГОРОСТАСИ ФИЗИЧКЕ КУЛТУРЕ РАФАЕЛ И ДУШАНКА БАН
}

\begin{abstract}
САЖЕТАК
Имајући могућност да одређено време живи са Бановима и анализирајући њихове биографске и библиографске податке као и целокупну њихову стручну литературу , аутор долази до закључка да су цео свој живот чланови породице Бан отац и ћерка посветили физичкој култури. Стваралаштво Рафаела и др Душанке Бан настало је на посебно негованом спортско соколском стилу живота. На основу целокупног стваралаштва аутор верује да постоје одређена врста људи, ретки и изузетни који уживају у напору стваралаштва за своју струку- физичку културу. Они постављају нове знакове преиспитивајући темељне премисе физичке културе како у теорији тако и у пракси.
\end{abstract}

Кључне речи: анализа биографских и библиографских података, стваралаштво, допринос, нове смернице

\section{ГИГАНТЫ ФИЗИЧЕСКОЙ КУЛЬТУРЫ РАФАЭЛЬ И ДУШАНКА БАН}

\begin{abstract}
АННОТАЦИЯ
Прожив некоторое время в семье Бан и проанализировав их биографические и библиографические данные, а также всю их научную работу, автор приходит к выводу, что члены семьи Бан, как отец, так и дочь, посвятили всю свою жизнь физической культуре. Опус Рафаэля и доктора Душанки Бан был основан на тщательно взращенном спортивном образе жизни. Основываясь на всем их опусе, автор считает, что есть люди определенного рода, редкие и экстраординарные, которые наслаждаются творческой деятельностью в своей области знаний - физической культуре. Они разрабатывают новые рекомендации и переосмысливают основополагающие предпосылки к занятиям физической культурой как в теории, так и на практике.
\end{abstract}

Ключевые слова: анализ биографических и библиографических данных, творчество, вклад, новые рекомендации 